\title{
Lietuvos pirmininkavimas ES Tarybai bendros saugumo ir gynybos politikos srityje: galimybès ir uždaviniai ${ }^{\star \star}$
}

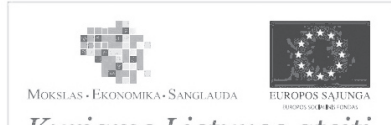

\section{Kuriame Lietuvos ateiti}

Viena iš svarbiausių Lisabonos sutartyje numatytų pertvarkų - tai valstybių narių pirmininkavimo Bendros užsienio ir saugumo politikos (BUSP) srityje reorganizacija, didžiąją su pirmininkavimu susijusių funkcijų dalį atiduodant naujai įsteigtoms institucijoms: Europos Sąungos (ES) vyriausiajam igaliotiniui (ESVĮ) ir Išorès veiksmų tarnybai (IVT). Šis funkcijų perskirstymas lemia tai, kad valstybių narių pirmininkavimo vaidmenys BUSP ir BSGP srityse iš esmés keičiasi. Lietuvai rengiantis pirmininkauti ES Tarybai 2013 m. kyla klausimas, kokias funkcijas ji išlaikys kaip pirmininkaujančioji valstybe šiose srityse. Straipsnyje siekiama apibrěži BUSP sudedamosios dalies Bendros saugumo ir gynybos politikos (BSGP) institucinę pirmininkavimo aplinką ir pagrindinius pirmininkavimo vaidmenis po Lisabonos sutarties įsigaliojimo bei numatyti galimus sèkmingo pirmininkavimo veiksnius. Straipsnis remiasi tyrimu, atliktu $2011 \mathrm{~m}$. pavasarị Ministro Pirmininko tarnybos užsakymu. Šio tyrimo metu buvo atlikti interviu su 2 ES institucijų atstovais bei su BSGP srityje dirbančiais ekspertais iš Lietuvos, Lenkijos, Belgijos, Vengrijos ir Airijos.

\section{Ivadas}

2013 metų antrąji pusmetį Lietuva rengiasi pirmą kartą pirmininkauti ES Tarybai. Pirmininkavimas, net jei valstybe ir neturi itin didelių tikslų ir ambicijų, reikalauja pastangų ir kruopštaus pasirengimo. Lietuvos pasirengimą apsunkina ne tik tai, kad ji dar neturi pirmininkavimo patirties, bet ir tai, kad po Lisabonos sutarties įsigaliojimo pirmininkavimo aplinka bei pirmininkaujančiojo vaidmenys vis dar nèra iki galo nusistovëję. Taigi, siekiant gerai pasiruošti pirmininkavimui,

\footnotetext{
* Dr. Margarita Šešelgyté - Vilniaus universiteto Tarptautinių santykių ir politikos mokslų instituto direktoriaus pavaduotoja. Adresas korespondencijai: Vokiečių g. 10, 01130 Vilnius, tel. (8 5) 251 4132, el. paštas: margarita.seselgyte@tspmi.vu.lt.

** Tyrimas finansuotas Ministro Pirmininko tarnybos vykdyto projekto „Lietuvos Europos Sąjungos reikalų sistemos efektyvumo didinimas" (Nr. VPI-4.2-VRM-05-V-02-001 lěšomis).
} 
tenka nuolat stebèti, kokie pirmininkavimo vaidmenys ir funkcijos ryškejja tose srityse, kurias paveikè Lisabonos sutartis, kaip pirmininkaujančioms valstybèms sekasi įveikti kylančius iššǔkius. Lisabonos sutartyje ypač daug dèmesio skirta Bendrai užsienio ir saugumo politikai (BUSP) ir jos sudedamajai daliai - Bendrai saugumo ir gynybos politikai (BSGP). Pakinta pastarųju statusas, įtvirtinamos naujos institucijos, nauji ipareigojimai, tokie kaip solidarumo bei bendros gynybos sąlygos, nauji bendradarbiavimo formatai (nuolatinio struktūruoto bendradarbiavimo principas). ${ }^{1}$ Lisabonos sutartis taip pat numatè reorganizuoti valstybių narių pirmininkavimo ES Tarybai BUSP srityje tvarką, išores santykių dalį atiduodant ES vyriausiojo iggaliotinio atsakomybei (anksčiau už šią sritį atsakinga buvo pirmininkaujanti valstybè). Šie pokyčiai kuria naują pirmininkavimo BUSP srityje aplinką ir skatina naujai įvertinti valstybių narių galimybes veikti šioje naujoje aplinkoje.

Straipsnis remiasi autorès tyrimu, atliktu 2011 m. pavasarị LR Ministro Pirmininko tarnybos užsakymu. Straipsnio tikslas - apibrèžti pirmininkaujančios valstybès vaidmenis BSGP srityje, ịvertinti jų reikšmę bei numatyti efektyvaus pirmininkavimo šioje srityje veiksnius. Viena iš pagrindinių problemų, kilusi rašant straipsni, - stoka akademinès literatūros, vertinančios pirmininkavimą šioje srityje įsigaliojus Lisabonos sutarčiai. Todel tiek tyrimas, tiek straipsnis daugiausia remiasi empiriniais duomenimis, t. y. $2011 \mathrm{~m}$. pavasarị atliktais septyniais interviu: su pirmininkavimo BSGP srityje klausimus kuruojančiais (ar tos šalies pirmininkavimo metu kuravusiais) Airijos, Belgijos, Lenkijos, Lietuvos, Vengrijos bei dviem ES pareigūnais.

\section{Bendra saugumo ir gynybos politika po Lisabonos sutarties: instituciniai pokyčiai}

BUSP ir BSGP institucinė struktūra ịsigaliojus Lisabonos sutarčiai pasikeitè. Šie pokyčiai veikia pirmininkavimo aplinką ir koreguoja pirmininkavimo vaidmenis. Pagrindinès aukščiausio politinio lygmens institucijos BSGP srityje yra Taryba, ES vyriausiasis igaliotinis užsienio reikalams ir saugumo politikai (ESVI̦) ir Politinis ir saugumo komitetas (PSK). Nors apskritai Lisabonos sutartis sustiprino Europos Parlamento vaidmeni sprendžiant ịvairius ES klausimus, BSGP srityje jo vaidmuo iš esmés nepasikeite. ${ }^{2}$ Taigi siekiant įvertinti pirmininkavimo galimybes politiniame lygmenyje verta apžvelgti pasikeitusias šių institucijų funkcijas po Lisabonos sutarties įsigaliojimo, jų tarpusavio galių balansą bei pirmininkaujančios valstybès vaidmeni jose.

\footnotetext{
${ }^{1}$ Plačiau Šešelgytè M., Lelevičiūtè I., Lisabonos sutarties poveikis ES bendrai saugumo ir gynybos politikai, Lietuvos metine strateginé apžvalga 2010-2011, p. 95-126.

${ }^{2}$ Treaty of Lisbon, 36 article.
} 
1 lentelè. Pagrindinès Taryboje sprendimus priimančios institucijos

\section{BSGP klausimais}

\begin{tabular}{|c|c|c|}
\hline Taryba* & $\begin{array}{c}\text { Sajungos vyriausiasis } \\
\text { ịgaliotinis užsienio } \\
\text { reikalams } \\
\text { ir saugumo politikai }\end{array}$ & $\begin{array}{c}\text { Politinis ir saugumo } \\
\text { komitetas }\end{array}$ \\
\hline $\begin{array}{l}\text { Sprendimus dèl BUSP } \\
\text { priima vieningai, rem- } \\
\text { damasi ESVỊ pasiūlymu } \\
\text { arba valstybès narès }^{\text {iniciatyva }}{ }^{\star *}\end{array}$ & $\begin{array}{l}\text { Prižiūrimas Tarybos ir } \\
\text { palaikydamas glaudų ryšį } \\
\text { su Politiniu ir saugumo } \\
\text { komitetu, užtikrina misijų } \\
\text { civilinių ir karinių aspektų } \\
\text { koordinavimą } \\
\text { Vykdo bendrą užsienio ir } \\
\text { saugumo politiką }{ }^{\star \star \star ~} \\
\text { Formuoja Tarybos darbo- } \\
\text { tvarkę }\end{array}$ & $\begin{array}{l}\text { Atlieka krizių valdymo opera- } \\
\text { cijų politinę kontrolę ir joms } \\
\text { strategiškai vadovauja }^{* \star \star \star}\end{array}$ \\
\hline
\end{tabular}

Iki Lisabonos sutarties ịsigaliojimo vienas svarbiausių veikëjų priimant sprendimus dèl BSGP buvo BRIST (Bendrųjų reikalų ir išorès santykių taryba). Lisabonos sutartis pastarąją išskyre į dvi atskiras tarybas: Bendrujjų reikalų ir Išorés reikalų. ${ }^{3}$ Išores reikalų tarybai (IRT) suteikta galimybe koncentruoti savo veiklą ties užsienio ir saugumo politikos klausimais, kurių apimtys pastaraisiais metais ES labai išaugo. Lisabonos sutartis taip pat įtvirtina naujas institucijas: Europos Vadovų Tarybos (EVT) pirmininką, ESVĮ, Išores veiksmų tarnybą (IVT). ${ }^{4}$ ESVİ kartu su valstybemis naremis vykdo bendrą užsienio ir saugumo politiką, pirmininkauja IRT, o taip pat yra Europos Komisijos (EK) vicepirmininkas; jis turi iniciatyvos teisę plètojant bendrą užsienio ir saugumo politiką, užtikrina EVT ir IVTT sprendimų igyvendinimą; atstovauja ES BUSP reikaluose bei santykiuose su trečiosiomis šalimis, taip pat reiškia ES poziciją tarptautinèse organizacijose. ${ }^{5}$ Tokiu būdu ESVİ tampa pagrindiniu BUSP gairių brěžèju ir ịgyvendinimo prižiūrètoju. BSGP srityje ESVĮ ne tik brěžia gaires, bet kartu su Taryba taip pat koordinuoja ES misijas bei yra atsakingas už jų igyvendinimą ${ }^{6}$

\footnotetext{
* Nors Lisabonos sutartyje už BSGP klausimus yra atsakinga Išorès reikalų taryba, kurioje pagrindinį vaidmenį vaidina valstybių narių užsienio reikalų ministrai, įsigaliojus Lisabonos sutarčiai de facto formuojasi atskira gynybos reikalų taryba. Nebelieka bendrų užsienio reikalų ir gynybos ministrų sesijų, šie skirtingo lygio susitikimai vyksta ne vienu metu. Gynybos ministrai tvirtina pirmininkavimo išvadas saugumo ir gynybos srityje.

** Treaty of Lisbon, 42.4 article.

*** Treaty of Lisbon, 43.2; 24.1 articles.

**** Treaty of Lisbon, 38 article. ${ }^{3}$ Treaty of Lisbon , 16.6 article.

${ }^{4}$ Treaty of Lisbon , 15; 18; 27; 45 articles.

${ }^{5}$ Treaty of Lisbon, 26.3, 27.1, 27.2 articles.

${ }^{6}$ Treaty of Lisbon, 30.2 articles.
} 
İsigaliojus Lisabonos sutarčiai viena svarbiausių institucijų BSGP (įtakos prasme), gal net svarbesnè už IRT, išlieka Politinis ir saugumo komitetas (PSK) ${ }^{7}$. PSK iš esmés yra paskutine grandis sprendimų prièmimo procese prieš pateikiant BSGP klausimus svarstyti Tarybai. Pagrindiniai Lisabonos sutartyje įtvirtinti su PSK susiję pokyčiai yra tai, kad PSK bus atskaitingas dviem „vadovams“: kolegialiai Tarybai ir ESVİ atstovui, taip pat tai, kad PSK darbotvarkę formuos ESVI kabinetas, o pirmininkaus ESVI atstovas (anksčiau pirmininkaudavo valstybè narè).

Šie Lisabonos sutartyje įtvirtinti pokyčiai leidžia diskutuoti apie Tarybos galių išaugimą kitų ES institucijų atžvilgiu. Wolfgangas Wesselsas teigia, kad įsigaliojus Lisabonos sutarčiai akivaizdžiai pasikeite Tarybos ir Komisijos galių balansas. ${ }^{8}$ Atskyrus IRT pastaroji igavo daugiau laiko ir gebëjimų koncentruotis ties užsienio ir saugumo klausimais. Ji brěžia pagrindines politikos gaires, taip pat išlieka „paskutine instancija“ kurioje balsuojama del vieno ar kito sprendimo. Iš EK atimta ,iniciatyvos teise““ perleista ESVIt, kuris yra atskaitingas tai pačiai IRT. ${ }^{9}$ PSK taip pat yra atskaitingas Tarybai ir ESVĮ. Taigi, galima teigti, kad aukščiausiame lygmenyje sprendimu priemimo galios BSGP klausimais koncentruojamos Taryboje bei jai atskaitingose institucijose. Taip pat galima daryti prielaidą, kad auga didžiųjų valstybių, kurios paprastai turi daugiau galios Taryboje, įtaka mažujų valstybių sąskaita.

Lisabonos sutartis taip pat numate, kad ESVĮ iš valstybiu narių perima pirmininkavimo IRT funkciją. ${ }^{10}$ Taigi, viena vertus, sudaromos galimybès užtikrinti ilgalaikiškesnę, nuoseklesnę bei efektyvesnę BSGP, kita vertus, sumažinamos valstybių narių galimybès formuoti ir veikti BSGP darbotvarkę. Tiesa, šios gali tai daryti keldamos klausimus EVT arba IRT, tačiau šie klausimai apsiriboja politiniu lygmeniu. ${ }^{11}$ Kita vertus, į tokius klausimus reaguojama tik tokiais atvejais, jei klausimą iškẻusi šalis turị nemažą politinę įtaką ar stiprią paramą iš kitų valstybių narių.

ES institucijų atstovas teigia, kad siekiant geriau suprasti institucinio balanso

\footnotetext{
${ }^{7}$ Treaty of Lisbon, 38 article. Politiniam ir saugumo komitetui pirmininkauja Europos Sajungos vyriausiojo iggaliotinio užsienio reikalams ir saugumo politikai atstovas. Šis komitetas stebi tarptautinę padetį bendrai užsienio ir saugumo politikai priklausančiose srityse ir, Tarybos prašymu, ESVİ prašymu ar savo iniciatyva pateikia Tarybai nuomones, prisideda prie politikos krypčių apibrě̌imo; stebi, kaip igyvendinamos sutartos politikos kryptys. Taip pat Politinis ir saugumo komitetas atlieka Petersbergo užduočių politinę kontrolę ir joms vadovauja. ${ }^{8}$ Wessels W. and Bopp F., „The Institutional Architecture of CFSP after the Lisbon Treaty- Constitutional breakthrough or challenges ahead?“. Challenge. Liberty \& Security. Research Paper No. 10, June 2008, p. 15. House of Common Foreign Affairs Committee. Foreign Policy Aspects of the Lisbon Treaty. Third report of the session 2007 - 2008, 20 p. http://www.publications.parliament.uk/pa/cm200708/cmselect/cmfaff/120/120. pdf [žiūrèta $2010 \mathrm{~m}$. gegužès $5 \mathrm{~d}$.]

${ }^{9}$ Treaty of Lisbon, 30.2 articles.

${ }^{10}$ Treaty of Lisbon, „Declaration on Article 16(9) of the Treaty on European Union concerning the European Council decision on the exercise of the Presidency of the Council”, 1 article.

${ }^{11}$ Europos Vadovų Taryba nustato BUSP, ịskaitant gynybinio pobūdžio reikalus, ES strateginius interesus, tikslus ir apibrěžia bendras gaires, priima reikiamus sprendimus; kai dèl tarptautines situacijos Europos Sąjungai reikia operatyviai veikti, reikalingus sprendimus taip pat priima Taryba. (Treaty of Lisbon, 26 ir 28 articles).
} 
pokytị po Lisabonos sutarties ịsigaliojimo būtina atskirti dvi funkcijas: darbotvarkès formavimą ir sprendimų prièmimą. Formuojant darbotvarkę galios balansas ryškiai pasikreipe link ES. ESVĮ kartu su savo pavaldiniais formuoja darbotvarkę. Valstybès nares praktiškai neturi jokių galimybių formuoti darbotvarkę, nebent per Tarybą, PSK ar kitais būdais bandyti paveikti ESVİ. Tačiau dèl tarpvyriausybinès BSGP prigimties valstybès narès išlieka svarbiausios veikëjos priimant sprendimus ir „formuojant užduotis" vyriausiajam igaliotiniui. ESVI̦ tèra šių sprendimų vykdytojas. Jo manymu, pagrindinè institucija, kur galima daryti įtaką sprendimams BSGP, yra PSK. ${ }^{12}$ Kita vertus, nereikia pamiršti, kad valstybių narių galimybès daryti poveiki šio politinio lygmens institucijų sprendimams nèra susijusios su pirmininkavimu ir dažnai priklauso nuo valstybès politinès įtakos bei gebëjimo iš anksto užsitikrinti kitų valstybių narių paramą. Kitas ES institucijų atstovas pritare, kad vertinant galios balanso pokyčius būtina analizuoti skirtingas funkcijas, ir pabrèžè, kad tiek institucinis žemèlapis, tiek galios pusiausvyra po Lisabonos sutarties įsigaliojimo tebekinta. Visi pirmininkavimai, sekę po Lisabonos sutarties ịsigaliojimo, buvo labai skirtingi: belgai turëjo daugiau įtakos, o vengru galimybès kaip nors veikti darbotvarkę buvo labai ribotos. Jo nuomone, Vengrijos pirmininkavimas parode, kaip ateityje atrodys visų mažų valstybių pirmininkavimas BSGP srityje. Vieninteliai darbotvarkès įtakos kanalai eina per ESVIt, o tai gali daryti tik didžiosios valstybès (ir tai ne pavieniui) aukščiausiu lygmeniu, arba tos, kurios sugeba užsitikrinti stiprią ir plačią kitų valstybių paramą. Geriausias pavyzdys, kaip galima priversti ESVİ reaguoti - Veimaro laiškas (Prancūzija, Vokietija, Lenkija). I t tokias iniciatyvas ESVĮ negali neatsižvelgti. ${ }^{13}$ Mažos valstybes gali bandyti formuoti koalicijas vienu ar kitu klausimu ir derinti šiuos klausimus su ESVIt, bet tam būtina labai plati remiančiujjų koalicija, įtraukianti ir didžiąsias valstybes, o klausimas turi būti aktualus visai ES. Svarbu paminèti ir tai, kad dèl savo labai įtemptos darbotvarkès ir menko domejjimosi BSGP klausimais ${ }^{14}$ iš esmès visą BSGP kontrolę ESVĮ yra atidavęs savo pavaduotojui Maciejui Popowskiui, todèl dažnai vartojant ESVI̦ sąvoką iš tiesų turimas omenyje ESVİ pavaduotojas. Taigi, tiek darant poveikị darbotvarkei, tiek sprendimams aukščiausiu lygmeniu, valstybès narès turi gebèti iš anksto užsitikrinti plačią valstybių narių paramą.

Vis dèlto, kasdieninëje saugumo ir gynybos politikoje yra daug klausimų, nepatenkančių ị aukščiausią BSGP darbotvarkę, ir jie sprendžiami IVT, komitetuose bei grupèse. Pagrindinès šio lygmens institucijos - tai naujai issteigta IVT, Krizių valdymo civilinių aspektų komitetas (CIVCOM), Politiné-karinè grupé (PMG), Europos Sąjungos karinis komitetas (EUMC), Patarëjų užsienio santykių

\footnotetext{
${ }^{12}$ Interviu su ES institucijų atstovu (I), $2011 \mathrm{~m}$. gegužès $24 \mathrm{~d}$.

${ }^{13}$ Interviu su ES institucijų atstovu (II), $2011 \mathrm{~m}$. gegužè $19 \mathrm{~d}$.

${ }^{14}$ Interviu su Belgijos atstovu, $2011 \mathrm{~m}$. gegužes $5 \mathrm{~d}$.
} 
klausimais darbo grupe (RELEX). Pirmininkavimo funkcija ir šiame lygmenyje po Lisabonos sutarties atitenka ESVİ ir jo atstovams (tiesa, karinèms institucijoms jau iki Lisabonos sutarties įsigaliojimo pirmininkavo ES institucijų atstovai).

\section{2 lentelè. Kitos svarbiausios Taryboje esančios BSGP institucijos}

\begin{tabular}{|c|c|c|c|c|}
\hline $\begin{array}{l}\text { Europos } \\
\text { išorès } \\
\text { veiksmų } \\
\text { tarnyba }\end{array}$ & $\begin{array}{l}\text { Krizių valdy- } \\
\text { mo civilinių } \\
\text { aspektų } \\
\text { komitetas } \\
\text { (CIVCOM) }\end{array}$ & $\begin{array}{l}\text { Politinè-ka- } \\
\text { rinè grupé } \\
\text { (PMG) }\end{array}$ & $\begin{array}{l}\text { Europos Są- } \\
\text { jungos karinis } \\
\text { komitetas } \\
\text { (EUMC) }\end{array}$ & $\begin{array}{c}\text { Patarèjụ } \\
\text { užsienio } \\
\text { santykių } \\
\text { klausimais } \\
\text { darbo gru- } \\
\text { pè (RELEX) }\end{array}$ \\
\hline $\begin{array}{l}\text { Sudaryta iš Tary- } \\
\text { bos generalinio } \\
\text { sekretoriato, } \\
\text { Komisijos ir } \\
\text { valstybių nariu } \\
\text { deleguojamo } \\
\text { personalo. Ji pa- } \\
\text { deda Sajungos } \\
\text { vyriausiajam ịga- } \\
\text { liotiniui užsienio } \\
\text { reikalams ir sau- } \\
\text { gumo politikai } \\
\text { kurti pasiūlymus } \\
\text { ir ịgyvendinti po- } \\
\text { litiką, patvirtintą } \\
\text { Taryboje. }\end{array}$ & $\begin{array}{l}\text { Tai PSK darbo } \\
\text { grupè, kuri yra } \\
\text { atsakinga už } \\
\text { ivairius civilinius } \\
\text { krizių valdy- } \\
\text { mo aspektus. } \\
\text { Kuria civilinių } \\
\text { krizių valdymo } \\
\text { koncepcijas ir } \\
\text { instrumentus, } \\
\text { vertina strate- } \\
\text { gines alternaty- } \\
\text { vas, planuoja ir } \\
\text { prižiūri civilinių } \\
\text { operacijų vyk- } \\
\text { dymą. }\end{array}$ & $\begin{array}{l}\text { Atsakinga } \\
\text { už karines ir } \\
\text { mišrias ope- } \\
\text { racijas. Kuria } \\
\text { strategines } \\
\text { koncepcijas, } \\
\text { padeda rengti } \\
\text { planavimo } \\
\text { dokumentus ir } \\
\text { prižiūri opera- } \\
\text { cijų vykdymą. } \\
\text { Taip pat prižiūri } \\
\text { saugumo sek- } \\
\text { toriaus reformu } \\
\text { misijas bei } \\
\text { ES veiksmus } \\
\text { Afrikoje. } \\
\text { Atsakinga už } \\
\text { PSK susitikimụ } \\
\text { rengimą, taip } \\
\text { pat apiben- } \\
\text { drina ịvairių } \\
\text { darbo grupių, } \\
\text { komitetų, } \\
\text { nagrinejjančių } \\
\text { svarstomą } \\
\text { klausima, nuo- } \\
\text { mones ir teikia } \\
\text { rekomendaci- } \\
\text { jas PSK. }\end{array}$ & $\begin{array}{l}\text { Aukščiausia } \\
\text { karinè institu- } \\
\text { cija Taryboje, } \\
\text { kurią sudaro } \\
\text { valstybių nariụ } \\
\text { kariuomeniu } \\
\text { vadai, atstovau- } \\
\text { jami nuolatinių } \\
\text { atstovų. Jos } \\
\text { paskirtis - teikti } \\
\text { PSK rekomen- } \\
\text { dacijas ir patarti } \\
\text { kariniais klau- } \\
\text { simais ES. Šis } \\
\text { komitetas prižiūri } \\
\text { ES karines ope- } \\
\text { racijas ir vertina } \\
\text { strategines krizių } \\
\text { valdymo opcijas } \\
\text { bei pajègumu } \\
\text { generavimą, } \\
\text { teikia instrukcijas } \\
\text { Kariniam štabui. } \\
\text { Šiam komitetui } \\
\text { pirmininkauja Ta- } \\
\text { rybos paskirtas } \\
\text { karininkas } \\
\text { (3 metụ laikotar- } \\
\text { piui). }\end{array}$ & $\begin{array}{l}\text { Ši darbo gru- } \\
\text { pè yra atsa- } \\
\text { kinga už visus } \\
\text { horizontalius } \\
\text { klausimus } \\
\text { rengiant ir } \\
\text { vykdant Tary- } \\
\text { bos sprendi- } \\
\text { mus. }\end{array}$ \\
\hline
\end{tabular}

Vienas svarbiausių institucinių pokyčių BSGP srityje yra IVT ịsteigimas. 
IVT sudaro Tarybos generalinio sekretoriato ir Komisijos atitinkamų padalinių pareigūnai bei nacionalinių diplomatinių tarnybų komandiruotas personalas. ${ }^{15}$ I IVT EK dažniausiai deleguoja žmones iš RELEX generalinių direktoratu (Išores santykių, Prekybos ir Vystymosi), Taryba - iš Politikos padalinio ir Generalinio išorès ir politinių-karinių reikalų direktorato. ${ }^{16}$ IVT darbuotojai padeda ESVİ formuoti BSGP darbotvarkę, rengia dokumentus ir įgyvendina priimtus sprendimus. Nors vis dar sudetinga vertinti IVT vaidmenį BSGP dèl to, kad kolektyvas dar formuojasi, tam tikros tendencijos apčiuopiamos jau dabar. Pirma, IVT iš valstybių narių perima vis daugiau pirmininkavimo funkcijų. Antra, dèl kol kas IVT egzistuojančio institucinio delegavimo disbalanso (didžiąją dalį IVT pareigūnų sudaro Komisijos darbuotojai (1114 iš $1643)^{17}$ IVT galioja Komisijos darbo metodai. ES atstovas pažymejjo, jog tai, kad apie 90\% IVT yra atëję iš Komisijos, sukuria nepalankią institucijos santykių su valstybèmis narèmis atmosferą. Valstybès narès dažnai traktuojamos, kaip „priešai“, siekiantys savanaudiškų interesų, ir todèl jas siekiama patraukti iš sprendimu prièmimo proceso. Valstybèms narems nepalankią atmosferą sustiprina tai, kad egzistuoja nemažai vidinių įtampų, o IVT institucijos nèra iki galo suformuotos, darbo srautai per dideli esančiam žmonių skaičiui, funkcijos ne visada tinkamai padalytos. ${ }^{18}$ Panašu, kad ESVİ jau pastebejo IVT egzistuojančias problemas ir bando ị jas reaguoti. $2011 \mathrm{~m}$. gegužès viduryje vyko PSK posèdis, kurio metu buvo svarstoma BSGP ir IVT veikla. ESVI prašè valstybių narių pateikti savo nuomonę, tačiau tai, kad tos nuomonés paprašyta neformaliame lygmenyje, gali rodyti, kad artimiausiu metu egzistuojančių problemų nebus įmanoma išspręsti. ${ }^{19}$

Viena svarbiausių institucijų BSGP srityje tampa po Lisabonos sutarties ịsigaliojimo IVT struktūroje atsiradęs Krizių valdymo ir planavimo direktoratas (CMPD), kuris buvo suformuotas iš anksčiau egzistavusių civilinių ir karinių krizių valdymo struktūrų. ${ }^{20}$ Tokiu būdu bandoma sumažinti takoskyrą tarp civilinių ir karinių misijų, kita vertus, šis padalinys rimtai sustiprina IVT vaidmenị. CMPD funkcijos iš esmès yra tos pačios, kaip ir IVT, tik siauresnio pobūdžio, t.y. CMPD dirba išimtinai su BSGP klausimais. Taigi - BSGP srityje po ESVİ ir ESVIt pavaduotojo saugumo klausimais CMPD tampa viena svarbiausių institucijų,

\footnotetext{
${ }^{15}$ Lisbon Treaty, article 27.3.

${ }^{16}$ Vanhoonacker S., Reslow N., The European External Action Service: Living Forwards by Understanding Backwards. European Foreign Affairs Review, No. 15, 2010, p. 6-7.

${ }^{17}$ A New Step in the Setting- up of the EEAS: transfer of staff on 1 January 2011.

${ }^{18}$ Interviu su ES institucijų atstovu (I), $2011 \mathrm{~m}$. gegužès $24 \mathrm{~d}$.

${ }^{19}$ Interviu su ES institucijų atstovu (II), $2011 \mathrm{~m}$. gegužès $19 \mathrm{~d}$

${ }^{20}$ European Peace Building Liaison Office, Statement on Civilian and Military Integration in European Security and Defence Policy, 2009 January 3.
} 
formuojančiu darbotvarkę bei rengiančių dokumentus. Vis dèlto valstybių narių poveikio šiai institucijai galimybès yra labai ribotos. CMPD yra IVT dalis, kuri tiesioginių kontaktų su valstybemis naremis neturi, ir CMPD „pasiekti“ galima tik per kitas darbo grupes VI ar IVT. Valstybès narés gali formuoti užduotis VI tiesiogiai arba jas siūlyti per darbo grupes, ir tik tada VI jas perduoda CMPD. Kita vertus, kadangi CMPD rengia svarbius dokumentus bei turi daug svarbios informacijos, neformalūs kontaktai su šios tarnybos darbuotojais valstybei narei gali būti labai naudingi. ${ }^{21}$ ES atstovas teigia, kad nors ị CMPD daug žmonių atejo iš Tarybos, bet ir ten tvyro tas pats požiūris ị valstybes nares, kaip ir apskritai IVT. ${ }^{22}$ CMPD taip pat vis dar susiduria su neužimtų pareigu problema. Nors 2011 $\mathrm{m}$. balandžio mènesį darbą jau pradëjo naujas CMPD vadovas - belgas Walteris Stevensas, lieka daug laisvų etatų ekspertiniame lygmenyje.

Po ESVİ, PSK bei IVT įtakingiausios BSGP srityje yra Krizių valdymo civilinių aspektų komitetas (CIVCOM) bei Politinè-karinè grupe (PMG) ${ }^{23}$ Kariniais klausimais svarbus ir ES karinis komitetas (EUMC). ${ }^{24}$ Prieš patekdami į Tarybą visi klausimai būna apsvarstomi PSK. Tačiau prieš patekdami ị PSK visi klausimai yra derinami dar žemesniame lygmenyje - PMG, CIVCOM, CMPD. ${ }^{25}$ Todel darbas šiose institucijose yra labai svarbus tiek siekiant paveikti darbotvarkę, tiek formuoti tam tikras būsimų sprendimų gaires. Paminètina tai, kad pirmininkaujanti valstybe né vienoje iš šių institucijų įsigaliojus Lisabonos sutarčiai nepirmininkauja.

Dar viena Lisabonos sutartimi įtvirtinta institucija - Europos gynybos agentūra (EDA). Nors ši institucija jau veike kelerius metus (įkurta $2004 \mathrm{~m}$. remiantis Ministrų Tarybos bendraisiais veiksmais), Lisabonos sutartimi ji igijo naują statusą. Tai vienintelè ES agentūra, minima sutartyje. EDA, vadovaujama ESVİ, atlieka pagrindinį vaidmenį tobulinant valstybių narių karinius pajègumus. ${ }^{26} \mathrm{EDA}$ funkcijos taip pat siejamos su Lisabonos sutartimi įtvirtinto „nuolatinio struktūruoto bendradarbiavimo" igyvendinimu.

\footnotetext{
${ }^{21}$ Interviu su ES institucijų atstovu (I), $2011 \mathrm{~m}$. gegužès $24 \mathrm{~d}$.

${ }^{22}$ Ten pat.

${ }^{23}$ Ten pat.

${ }^{24}$ Interviu su ES institucijų atstovu (II), 2011 m. gegužè 19 d.

25 Ten pat.

${ }^{26}$ The Treaty of Lisbon, Article 42.3.
} 


\section{3 lentelè. Kitos BSGP institucijos, komitetai bei darbo grupès}

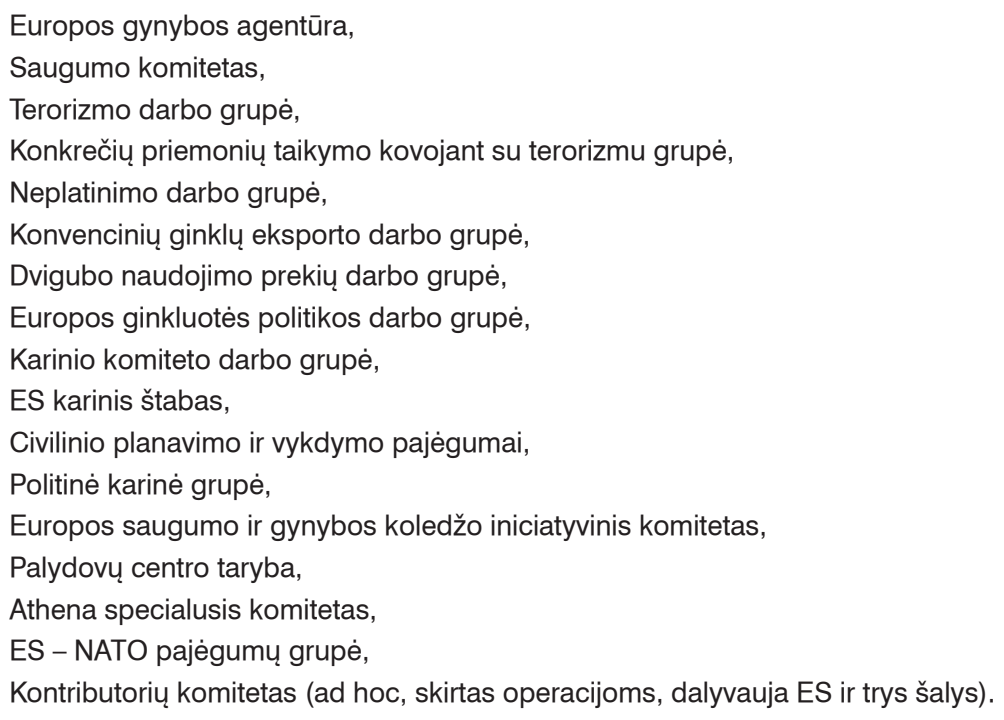

İsigaliojus Lisabonos sutarčiai galimybę pirmininkauti (t.y. formuoti darbotvarkę ir pirmininkauti susitikimams) valstybès nares prarado ir kitose, žemesnio lygmens BSGP institucijose. Pirmininkavimo galimybe išlieka tik Terorizmo darbo grupeje (COTER), Europos saugumo ir gynybos koledžo (ESDC) iniciatyviniame komitete bei Athena specialiajame komitete, Konkrečiu priemonių taikymo kovojant su terorizmu (COCOP) darbo grupejje. Tiesa, net tose darbo grupèse, kurioms pirmininkauja ES institucijų atstovai, teorinès įtakos galimybès išlieka, bet jos labai priklauso nuo valstybès nares santykių su grupés pirmininku ir ESVİ. ${ }^{27}$ Tarpvyriausybinès institucijos išlieka valstybių narių rankose, t.y. Palydovų centras (SATCEN), EDA ir Athena mechanizmas. Nors po Lisabonos EDA turètų keistis, bet kol kas palikta tarpvyriausybine. Vis deltto, neaišku, kiek šios institucijos pasikeis iki Lietuvos pirmininkavimo. ${ }^{28}$

Taigi, pagrindinès institucijos pirmininkaujant BSGP srityje yra ESVİ bei IVT, taip pat CIVCOM, PSK bei PMG, t.y. aukščiausio lygmens institucijos, kuriu sprendimai eina į Tarybą. Todèl pirmininkaujančiai valstybei būtina aktyviai veikti ypač šiuose formatuose. Viena svarbiausių veiklų - dirbti su valstybèmis naremis siekiant užsitikrinti jų paramą bei nuolatine koordinacija su ESVĮ. Teoriškai net žemiausio lygmens institucijos gali formuoti klausimą ir jị kelti ị IVT, tačiau tai ilgai užtrunka, daug priklauso nuo pirmininkaujančiojo bei valstybès narès gebé-

\footnotetext{
${ }^{27}$ Interviu su ES institucijų atstovu (I), $2011 \mathrm{~m}$. gegužès $24 \mathrm{~d}$.

${ }^{28}$ Interviu su LT atstove Briuselyje (I), $2011 \mathrm{~m}$. balandžio $27 \mathrm{~d}$.
} 
jimo kitas valstybes nares įtikinti stipriai remti iniciatyvą. Siekiant, kad klausimas pasiektų darbotvarkę pirmininkavimo metu, valstybẻ naré turètų pradèti aktyvius veiksmus bent porą metų prieš pirmininkavimą.

\section{Pirmininkavimo funkcijos BSGP issigaliojus Lisabonos sutarčiai}

Pirmininkavimo vaidmuo ES keitesi pastarajai evoliucionuojant, nuo daugiau organizacinio pobūdžio pagalbos ES institucijoms, kad nereiketų „išpūsto“ sekretoriato (trijų mènesių pirmininkavimas Anglių ir plieno bendrijai ir šešių ménesių pirmininkavimas Europos Ekonominei Bendrijai), iki rimtesnio vaidmens, įtraukiant ir tarpininkavimo funkcijas nuo šeštojo dešimtmečio. Vèliau formavosi dar viena svarbi funkcija - politinio lyderio funkcija, tačiau ambicijų pastarąją igyvendinti galëjo turèti tik didžiausios ir įtakingiausios valstybès. Slenkant metams keitesi ne tik funkcijos, klausimų turinys, bet ir darbo apimtys. Po paskutiniosios plètros dèl padidëjusio narių skaičiaus ir išsiplètusio klausimų rato pirmininkavimas tapdavo rimtu iššūkiu pirmininkaujančioms šalims. Ypač išaugo BUSP aprepiamų sričių laukas. Tai buvo viena iš priežasčių, lèmusių tai, kad Lisabonos sutartis nuo Bendrųjų reikalų ir išorès santykių tarybos atskyrẻ IRT ir pavedè pastarajai kuruoti šiuos klausimus. Lisabonos sutartis ne tik įsteigè naujas institucijas, bet ir numate joms svarbius vaidmenis. Kitaip nei kitoms Taryboms, kurioms 18 mèn. laikotarpiui pirmininkauja iš anksto numatytos trijų valstybių narių grupés, sudarytos lygios rotacijos tarp valstybių narių pagrindu, atsižvelgiant i j jų ívairovę ir geografinę pusiausvyrą Sąjungoje, Išorés reikalų tarybai pirmininkauja nuolatinis atstovas - ESVI.. ${ }^{29}$ Š is pirmininkavimo institucinès struktūros pakeitimas bei funkcijų perskirstymas iš esmès pakoregavo pirmininkaujančių valstybių vaidmenị BUSP. Erika M. Szabó teigia, kad įsigaliojus Lisabonos sutarčiai nebegalima kalbėti apie tradicini pirmininkavimą, o pagrindinis tyrinètinas klausimas - ar rotacijos principu vykstantis pirmininkavimas išvis išlieka ES išorès santykiuose. ${ }^{30}$

Akademinëje literatūroje gausu straipsnių, nagrinëjusių pirmininkavimo

\footnotetext{
${ }^{29}$ Treaty of Lisbon, „Declaration on Article 16(9) of the Treaty on European Union concerning the European Council decision on the exercise of the Presidency of the Council”, 1 article.

${ }^{30}$ Szabó E. M., Background Vocals: What Role for the Rotating Presidency in the EU's External Relations post-Lisbon?. EU Diplomacy Paper, 05 / 2011, Department of EU International Relations and Diplomacy Studies, College of Europe. http://aei.pitt.edu/32319/1/EDP_5_2011_ErikaSzabo.pdf [žiūrèta 20120208]
} 
vaidmenis išores santykių srityje iki Lisabonos sutarties įsigaliojimo. ${ }^{31}$ Skiriamos šios pagrindinès pirmininkavimo funkcijos: a) Tarybos darbo organizavimas - ES valstybių atstovų susitikimų Tarybos komitetuose, darbo grupèse ir kt. organizavimas bei logistika, Tarybos veiklos koordinavimas kartu su Tarybos sekretoriatu; b) tarpininkavimas ir kompromisų paieška (tiek tarp konkrečių ES valstybių, tiek tarp ES valstybių ir Europos Komisijos); c) politine lyderyste - ES politikos tikslų ir prioritetų nustatymas; $d$ ) vidine (ES su kitomis institucijomis) ir išorinè (santykiai su likusiu pasauliu) reprezentacija. ${ }^{32}$ Šios funkcijos siejamos su trimis pagrindiniais lyderio vaidmenimis, išskiriamais lyderystès teorijoje (i užduoties atlikimą orientuota lyderysté, i grupę orientuota lyderyste ir transformacine lyderyste்), ${ }^{33}$ kurie turi ne tik skirtingas funkcijas, bet ir tampa aktualūs skirtingose situacijose. Kai svarbiausiu uždaviniu tampa jau priimto sprendimo igyvendinimas, išryškejja ị užduoties atlikimą orientuotos lyderystès poreikis, kai reikia pokyčių, sustiprëja politinès, transformacinés lyderystès paklausa.

Dar viena svarbi pirmininkavimo funkcija - nacionalinių interesų atstovavimas. ${ }^{34}$ Ši funkcija labiausiai kontroversiškai vertinama dèl to, kad yra nesuderinama su pirmininkavimo filosofija, pagal kurią pirmininkas turi būti neutralus. Tačiau pirmininkavimo istorijoje visos valstybès, priklausomai nuo gebejimų ir išteklių, daugiau ar mažiau sieke savo nacionalinius interesus perkelti į ES darbotvarkę. Vis delto, įsigaliojus Lisabonos sutarčiai, tokiose srityse, kaip BUSP ir BSGP tai daryti praktiškai tapo neįmanoma, nes pirmininkaujanti valstybè nebeformuoja darbotvarkès. Dar viena pirmininkavimo funkcija, kurios nebelieka po Lisabonos sutarties įsigaliojimo, - tai reprezentacine funkcija. Tiek išorine, tiek vidine reprezentacija patenka į ESVI atsakomybès sritị. Nors ne taip drastiškai pakito ir kitos pirmininkavimo funkcijos BSGP srityje. Darbotvarkès formavimo bei pirmininkavimo komitetams bei darbo grupèms funkciją atidavus ESVI bei IVT, pirmininkaujanti valstybe prarado dalị organizacinių funkcijų. Tradicinio pirmininkaujančių valstybių tarpininkavimo funkcijų praktiškai visai neliko, nes

\footnotetext{
${ }^{31}$ Bengtsson R., "The Council Presidency and external representation”, in O. Elgström (ed.), European Union Council presidencies : a comparative perspective, London, Routledge, 2003; . Fernandez A.M.,

Change and Stability of the EU Institutional System: the Communitarization of the Council Presidency, Journal of European Integration, vol. 30. no. 5.; Schout A., Vanhoonacker S., The rotating Presidency: obstinate of obsolete, Journal of Common Market Studies, vol. 44, no. 5, 2006.

${ }^{32}$ Aleksa K., Grubliauskas J., Statkus N., Vaičiūnas Ž., Žielys P., Vokietijos, Portugalijos ir Slovenijos pasirengimo pirmininkauti Europos Sajungai lyginamoji analize, Vilniaus universitetas, 2007, p. 10; Quaglia L., Moxon - Browne E., what makes a good EU presidency? Italy and Ireland Compared, JCMS, Vol. 44, No. 2, p. 349 - 368. . Schout A., Vanhoonacker S., Evaluating Presidencies of the Council of the EU: Revisiting Nice, JCMS, Vol. 44, No. 5. p.1053-1056.

${ }^{33}$ Yukl G., Leadership in Organizations, Upper Saddle River, NJ: Prentince Hall, $4^{\text {th }}$ ed. 1998.

${ }^{34}$ Schout A., Vanhoonacker S., Evaluating Presidencies of the Council of the EU: Revisiting Nice, JCMS,

Vol. 44, No. 5. p. 1055.
} 
jos buvo atiduotos ị komitetų ir darbo grupių, t.y. ESVİ bei IVT rankas. Politinès lyderystès funkcija, kuri ir taip tekdavo tik didžiausioms ir stipriausioms valstybèms narèms, per darbotvarkès iniciatyvos teisę bei darbotvarkès igyvendinimo funkciją perëjo taip pat į ESVİ rankas.

Didžiajai daliai pirmininkavimo funkcijų perëjus į ESVİ ir jai pavaldžios IVT atsakomybès ribas, pirmininkaujančios valstybes vaidmuo BUSP ir BSGP srityse gerokai sumenko, todel ekspertų diskusijose pirmininkavimas vis dažniau yra apibrežiamas kaip ESVI „pagalbininko“, o ne savarankiško pirmininko vaidmuo. Wolfgangas Wesselsas tvirtina, kad Lisabonos sutartimi įsteigta Vyriausiojo igaliotinio pozicija yra komplikuota, per daug priklausanti nuo kitų institucijų, vykdanti per daug įvairių bei nepakankamai apibrežtų užduočių ir turinti per mažai pagalbininku, ${ }^{35}$ taigi pirmininkaujančios valstybès užduotis ir yra suteikti reikalingą pagalbą ESVİ. Vis dẻlto, apžvelgus po Lisabonos sutarties įsigaliojimo jau pirmininkavusių valstybių patirtį, galima teigti, kad „pagalbininko“ funkcijos bei įtaka gali skirtis.

Kadangi po Lisabonos sutarties įsigaliojimo pirmininkavo tik keturios valstybès, kol kas yra sudètinga tiksliai apibrěžti visas pirmininkavimo funkcijas polisaboninëje sistemoje, tuo labiau kad jos šiek tiek keičiasi plečiantis ir stiprëjant ESVİ. Priklausomai nuo pirmininkaujančios valstybès ambicijų lygmens po Lisabonos sutarties pirmininkavimas apibrěžiamas kaip „lengvinantis“" (angl. facilitating presidency) ${ }^{36}$ arba „remiantis“ (angl. supporting presidency). ${ }^{37}$ Iš esmes, šie abu pirmininkavimo tipai reiškia talkinimą, pagalbą ESVİ ir IVT, o ne savarankišką pirmininkavimą, tačiau „lengvinantis“ pirmininkavimas yra siejamas su Belgijos pirmininkavimu ir reiškia aukštesnį ambicijų lygmenị, kuomet pirmininkaujantis yra ne tik renginių organizatorius, bet šiek tiek ir idejju generatorius bei tarpininkas, o „remiantis“ pirmininkavimas - taip vengrai įvardijo savo pirmininkavimą - apsiriboja tik technine organizatoriaus funkcija. Interviu su ES institucijų atstovu rodo, kad polisaboniniu laikotarpiu buvo keturios pirmininkavimo BSGP srityje fazès: 1) Ispanijos pirmininkavimo metu vyravo chaosas, nebuvo darbotvarkès, nevyko susitikimai, IVT neegzistavo; 2) Belgijos pirmininkavimas - mišrus pirmininkavimas, kurio metu belgai pasiūle tam tikrą darbotvarkę, o VỊ jai pritarè. Nors pagal Lisabonos sutartį Belgija jau neturëjo pirmininkauti BSGP srityje, dèl žmogiškųju išteklių IVT trūkumo Belgija atliko daug tų pačių funkcijų, kaip ir pirmininkaujan-

\footnotetext{
35 Wessels W. and Bopp F., „The Institutional Architecture of CFSP after the Lisbon Treaty- Constitutional breakthrough or challenges ahead?“. Challenge. Liberty \& Security. Research Paper No. 10, June 2008, p.Wessels W., p. 23.

${ }^{36}$ Interviu su Lietuvos atstove Briuselyje (I), $2011 \mathrm{~m}$. balandžio $27 \mathrm{~d}$.

${ }^{37}$ Konsultacijų su Belgijos gynybos ministerijos pirmininkavimo ES komandos pirmininku plk. Johan Andries atmintine, $2011 \mathrm{~m}$. sausio $20 \mathrm{~d}$.
} 
čios valstybès prieš Lisabonos sutarties įsigaliojimą; 3) Vengrijos pirmininkavimo metu IVT jau turejjo savo programą bei pirmininkavimą aptarnaujantị personalą, todèl vengrams liko labai mažai funkcijų ${ }^{38}$; ir 4) Lenkijos pirmininkavimas, kuris pradžioje leido tiketis pokyčių, t.y. aktyvesnio pirmininkavimo, pasibaigus buvo vertinamas kaip pasyvus, nes Lenkija beveik neturëjo įtakos nei darbotvarkès formavimui, nei sprendimams. ${ }^{39}$

Dèl vis dar kintančios pirmininkavimo aplinkos labai atsargiai derètų vertinti tiek pirmininkavimo vaidmenis, tiek valstybių gebëjimus tuos vaidmenis igyvendinti. Bendra tendencija rodo, kad pirmininkavimo vaidmuo BSGP mažeja, tačiau kyla klausimas, ar yra šio mažejimo ribos, ar pirmininkaujančioji šalis gali nors kiek daryti įtakos savo vaidmeniui? Vengrijos pirmininkavimo komandos atstove interviu tvirtino, kad vengru pirmininkavimo laikotarpio „remiančiojo“ vaidmuo gali būti tapatinamas su neegzistuojančiu valstybès pirmininkavimu. ${ }^{40}$ Jai antrino Airijos gynybos ministerijos atstovas, tvirtindamas, kad po Lisabonos sutarties įsigaliojimo pirmininkavimas tapo labai pasyvus. Tai ypač matoma pirmininkavimo veikloje Briuselyje, tačiau ir sostinejje galimybès yra labai ribotos. ${ }^{41}$ Kita vertus, ES aukšto rango pareigūnas interviu teigè, kad pirmininkavimo vaidmuo vis dar daug priklauso nuo pirmininkaujančios valstybès pasirengimo ir iniciatyvos. ${ }^{42}$ Prieš prasidedant Lenkijos pirmininkavimui tuo buvo įsitikinusi ir Lenkijos atstovè. Ji teigè, kad skirtingai nei pasyvūs vengrai lenkai bent jau sieks tapti proceso dalimi. Kaip ir numatyta Lisabonos sutartyje, jie darbotvarkès neformuos, bet sieks ją paveikti, konsultuoti ESVI, skatinti kai kurias diskusijas. ${ }^{43}$ Todèl panašu, kad vieningo apibrežimo, kas yra pagalbininkas pirmininkaujant nèra, ir tai gali priklausyti nuo valstybès ambicijų ir ịtakos. Prieš prasidedant Lenkijos pirmininkavimui buvo tikimasi, kad jis gali šiek tiek pakreipti galios centrą link pirmininkaujančios valstybès. Tačiau lenkams to padaryti nepasisekè. Valstybių nariu galių sustiprëjimo neverta tikètis nei iš $2012 \mathrm{~m}$. pirmoje puseje pirmininkavusios Danijos, nei iš veliau pirmininkausiančių Kipro bei Airijos.

Kol pirmininkavimo vaidmuo išlieka neapibrěžtas, sudetinga tiksliai įvardyti su pirmininkavimu susijusias funkcijas. Tačiau ịvertinus pirmininkavusių valstybių patirtị ryškejja keletas bendrų tendencijų, t.y. tradicinès funkcijos pirmininkavimo struktūroje po Lisabonos sutarties ịsigalëjimo ne tik siaurëja, bet kinta ir jų pobūdis. Lietuvos atstovas nuolatinëje atstovybëje prie ES pabrèžè, kad pirmininkavimas

\footnotetext{
${ }^{38}$ Interviu su ES institucijų atstovu (II), 2011 m. gegužè 19 d.

${ }^{39}$ Kaczynski P. M., Polish Council Presidency 2011: Ambitions and Limitations, SIEPS, 2011.

${ }^{40}$ Interviu su Vengrijos atstove Briuselyje, $2011 \mathrm{~m}$. gegužès $4 \mathrm{~d}$.

${ }^{41}$ Interviu su Airijos atstovu Briuselyje, $2011 \mathrm{~m}$. gegužè $10 \mathrm{~d}$.

${ }^{42}$ Interviu su ES institucijų atstovu (I), $2011 \mathrm{~m}$. gegužès $24 \mathrm{~d}$.

${ }^{43}$ Interviu su Lenkijos atstove Briuselyje, $2011 \mathrm{~m}$. gegužès $18 \mathrm{~d}$.
} 
dabar iš esmès apima dvi funkcijas: renginių sostineje ir Briuselyje organizavimą bei dalinį darbotvarkès koregavimą ${ }^{44}$ Atliktuose interviu išryškẻjo kelios pagrindinés pirmininkavimo po Lisabonos sutarties įsigaliojimo funkcijos: organizaciné, tarpininkavimo ir darbotvarkès koregavimo. Iš principo šios funkcijos didele dalimi sutampa su anksčiau buvusiomis, tačiau veiklos mastai visose yra smarkiai sumažèję, kaip ir pasikeitę veiklos būdai.

\subsection{Organizacinè funkcija}

Formalių ir neformalių renginių organizavimas visada buvo viena pagrindinių pirmininkavimo funkcijų. İsigaliojus Lisabonos sutarčiai ši funkcija neišnyko, tačiau pasikeite jos pobūdis. Formalių renginių organizavimas atiteko IVT, o valstybėms narèms liko neformalių renginių organizavimo darbai. Neformalūs tai pusiau akademinio pobūdžio renginiai, kurių tematiką siūlo ir darbotvarkes formuoja pirmininkaujanti valstybè arba neformalūs susitikimai. Pirmininkaujanti valstybe išlaiko neformalių susitikimų organizavimo funkciją (neformalūs ministrų susitikimai, neformalūs politikos direktorių, PSK, PMG, CIVCOM, RELEX, Athena mechanizmo grupių susitikimai). Taip pat išlieka galimybè prisidèti (bent jau finansiškai) prie dviejų Europos gynybos agentūros (EDA) renginių organizavimo pirmininkavimo metu. Vengrija BSGP klausimais organizavo apie 20-30 renginių. Dauguma jų vyko Vengrijoje, kai kurie - Briuselyje. Lenkijos atstove teige, kad lenkai taip pat turëjo organizuoti daug renginių, tačiau atkreipe dèmesi i tai, kad renginių organizavimas (ypač akademiniu) yra daugiau tradicija, o ne prievole, be to, jie brangiai kainuoja, todèl ateityje, ypač, mažesnès valstybès, tokios kaip Kipras ar Danija, gali ir iš viso atsisakyti tai daryti. ${ }^{45}$ Paminètina tai, kad nors pakankamai skeptiškai dèl pirmininkavimo BSGP srityje ateities valstybėms narèms nusiteikę vengrai tvirtina, jog vienintelès rimtos užduotys, kurios lieka pirmininkaujančiajai - logistiškai aptarnauti neformalius susitikimus sostineje bei pagalvoti, kokiomis temomis organizuoti seminarus sostineje. ${ }^{46}$ Šių egzistuojančių galimybių tinkamas išnaudojimas gali sustiprinti pirmininkaujančios valstybè įtaką. Lietuvos atstovas teigia, kad polisabonineje erdvëje įvairių neformalių, pusiau akademinių renginių organizavimas pasitelkiant IVT taps viena pagrindinių pirmininkavimo BSGP srityje funkcijų. Tokiuose renginiuose galima IVT siūlyti darbotvarkès temas, formuoti tiek pačių renginių tematiką, tiek renginių turini - kas bus diskutuojama renginyje. ${ }^{47}$ Tokie

\footnotetext{
${ }^{44}$ Interviu su Lietuvos atstovu Briuselyje (II), $2011 \mathrm{~m}$. gegužès $4 \mathrm{~d}$.

${ }^{45}$ Interviu su Lenkijos atstove Briuselyje, $2011 \mathrm{~m}$. gegužès $18 \mathrm{~d}$.

${ }^{46}$ Interviu su Vengrijos atstove Briuselyje, $2011 \mathrm{~m}$. gegužès $4 \mathrm{~d}$.

${ }^{47}$ Interviu su Lietuvos atstovu Briuselyje (III), 2011 m. gegužès $10 \mathrm{~d}$.
} 
renginiai, jei jie yra sèkmingai suorganizuojami ir jų temos būna gerai parinktos, gali tapti puikiu „laipteliu“ toms temoms ị „tikrąją ES darbotvarkę“. Lietuvos atstovas tvirtino, kad tokiu „laipteliu“ gali tapti ir neformalūs susitikimai. Čia paprastai vyksta įdomiausios diskusijos. Pavyzdžiui, $2011 \mathrm{~m}$. gegužès mènesị vykęs neformalus CIVCOM grupes susitikimas Budapešte buvo labai įdomus ir sèkmingas. Vengrams pavyko pasikviesti tinkamų žmonių iš IVT, o pastarieji kèle vengrams rūpimus klausimus pajëgumų srityje. Vyko labai geros diskusijos, išplatintas neịpareigojantis dokumentas, kuris gali vèliau tapti darbiniu. ${ }^{48}$ Taigi tiek neformalių savarankiškų renginių organizavimas, tiek neformalių susitikimų organizavimas iš anksto pasirengus ir pasiūlius įdomių idejjų gali išplesti pirmininkaujančios valstybès galias.

Prie organizacines funkcijos galima priskirti pirmininkavimą komitetams ir darbo grupèms. Po Lisabonos sutarties ịsigaliojimo šios funkcijos pirmininkaujanti valstybe praktiškai nebeatlieka. Nors ji vis dar organizuoja neformalius susitikimus, pastariesiems nepirmininkauja. Gynybos ministrų susitikimams pirmininkauja ESVİ, o politikos direktoriu neformaliems susitikimams - CMPD vadovas. Pagrindinèse aukščiausio lygmens BSGP institucijose pirmininkauja nuolatiniai pirmininkai. Vengrai teige, kad pirmininkauja tik 3-4 komitetams bei grupems, ${ }^{49}$ o Lietuvos atstove prognozavo, kad Lietuva pirmininkaus tik Athena grupei bei ESDC iniciatyviniam komitetui. ${ }^{50}$ Kita vertus, pirmininkaujanti valstybe turi būti pasirengusi pirmininkauti ir aukštesniame lygmenyje. Pavyzdžiui, sausio mẻnesi vykusio neformalaus gynybos politikos direktoriu susitikimo metu Vengrijoje, kadangi dar nebuvo paskirti nei EDA, nei CMPD vadovai, renginiui pirmininkavo vengras. ${ }^{51}$ Kadangi šiuo metu abu vadovai jau dirba, tokiu atvejų ateityje iškils mažiau. Kita vertus, abiejų ES institucijų atstovai pabrežè, kad pirmininkaujančios valstybès užduotis - įvairiais atvejais pavaduoti Vİ, kai šis yra užsièmęs. ${ }^{52}$

Todèl ypač svarbu, kad besirengianti pirmininkauti valstybẻ kauptų ekspertizę labai ịvairiais ES darbotvarkès klausimas ir būtų pasirengusi šią ekspertizę pateikti pirmininkavimo metu.

Šalia tiesioginių pirmininkaujančiojo BSGP srityje funkcijų egzistuoja ir alternatyvūs pirmininkavimo „kanalai“, kuriais galima naudotis siekiant kelti valstybei aktualius BSGP klausimus. Lietuvos atstovas pabrěže, kad pirmininkaujanti valstybe išlaiko pirmininkavimą dar daugelyje institucijų, kuriuose galima kelti su

\footnotetext{
${ }^{48}$ Ten pat.

${ }^{49}$ Interviu su Vengrijos atstove Briuselyje, $2011 \mathrm{~m}$. gegužès $4 \mathrm{~d}$.

${ }^{50}$ Interviu su Lietuvos atstove Briuselyje (I), $2011 \mathrm{~m}$. balandžio $27 \mathrm{~d}$.

${ }^{51}$ Interviu su Vengrijos atstove Briuselyje, $2011 \mathrm{~m}$. gegužès $4 \mathrm{~d}$.

${ }^{52}$ Interviu su ES institucijų atstovu (I), $2011 \mathrm{~m}$. gegužès 24 d., ir interviu su ES institucijų atstovu (II), 2011

m. gegužè $19 \mathrm{~d}$.
} 
BSGP susijusius klausimus (COREPER, Terorizmo darbo grupé, RELEX grupé, Plètros grupè). Dar vienas galimas formatas už Tarybos rèmų - Europos Parlamentas. Nors šioje institucijoje BSGP instituciškai atstovauja ESVĮ, pirmininkaujanti šalis gali bandyti kelti BSGP klausimus kitais aspektais, siūlyti rezoliucijas. Taip pat neatmetamas poveikis per kitas tarptautines organizacijas. Dabar sprendžiamas klausimas dèl ES veiksmų koordinacijos tarptautinèse organizacijose (PPO, ESBO, JTO), bet kol jis neišspręstas, galima taip pat per jas kelti saugumo ir gynybos klausimus..$^{53}$ Šiuo atveju ypač svarbi tampa gera koordinacija tarp pirmininkaujančių institucijų valstybès viduje.

Taigi, nors akivaizdu, kad pirmininkaujančiai valstybei lieka tik neformalioji organizaciné funkcija bei alternatyvūs „kanalai“, sèkmingai tuo besinaudojanti valstybè nare bent jau kol kas gali pasiekti, kad ES atkreiptų dèmesi i j jai rūpimus klausimus, o sekmingas organizacijos funkcijos igyvendinimas tampa bene svarbiausiu pirmininkavimo BSGP srityje akcentu.

\subsection{Darbotvarkès formavimas}

Darbotvarkès formavimo funkcija niekada negarantavo automatiško pirmininkaujančios valstybès prioritetų perkèlimo į ES lygmenį. Didelè dalis ES darbotvarkę pasiekusių klausimų būdavo paveldeta iš anksčiau pirmininkavusių valstybių, dalis - padiktuota išorinés aplinkos ir tik apie 5-10\% darbotvarkès galedavo koreguoti pirmininkaujanti valstybe..$^{54}$ İsigaliojus Lisabonos sutarčiai darbotvarkes formavimo funkcija atitenka ESVİ ir IVT. Tiesa, pirmininkaujančios valstybės galimybès savo nacionalinius interesus perkelti į ES darbotvarkę šiek tiek kinta, priklausomai nuo to, ar pirmininkavimas vykdomas iš sostinès, ar iš Briuselio, ir nuo to, koks pirmininkaujančios valstybès ambicijų lygmuo, tačiau Lisabonos sutartis šią funkciją išimtinai perleidžia ESVĮ ir IVT. Pirmininkaujanti valstybe kartu su kitomis trejeto valstybemis teberengia trejeto pirmininkavimo programą bei individualią pirmininkavimo programą, tačiau jos neformuoja prioritetų BUSP ir BSGP srityse.

Tiesa, jau pirmininkavusios valstybès šiuo klausimu turëjo nevienodą patirtị. Belgija savo pirmininkavimo metu sugebejo suformuoti prioritetus BSGP srityje ir pasiūlyti juos ESVİ. Ji taip pat sieke daryti ịtaką pirmininkavimo darbotvarkei jau vykstant pirmininkavimui. Savo sèkmę belgai aiškino tuo, kad jie jau prieš

\footnotetext{
${ }^{53}$ Interviu su Lietuvos atstovu (IV), $2011 \mathrm{~m}$. balandžio $28 \mathrm{~d}$.

${ }^{54}$ Tallberg J. The Agenda - shaping Powers of the EU Council Presidency// Journal of European Public Policy, 10:1, February, 2003, p. 3.
} 
prasidedant Belgijos pirmininkavimui ir jo metu ypač glaudžiai bendradarbiavo su ESVİ ir CMPD, buvo aktyvūs, siūlè tokias temas, kurios buvo aktualios ne tik belgams, bet įdomios ir svarbios tiek ES, tiek valstybèms narems. ${ }^{55}$ Vienas iš ES pareigūnų pripažino, kad svarbiausias belgų laimëjimas buvo neformalus ministrų susitikimas Gente. Jo metu Belgijai ne tik pavyko įtraukti į ES darbotvarkę sau rūpimus klausimus, bet kartu ir pelnyti žinomumą. Gento iniciatyva svarbi ir tuo, kad demesys jei nenuslūgo ir pasibaigus Belgijos pirmininkavimui. ${ }^{56}$ Vis delto verta atkreipti demesi $i \mathfrak{i}$ tai, kad Belgijos pirmininkavimo metu IVT dar nebuvo galutinai suformuota ir turëjo daug mažiau galių bei ambicijų, todèl tai, kad belgai kažką pasiūle, tiesiog buvo patogu abiem pusems ir ne visai priklause nuo belgu sugebëjimo paveikti darbotvarkę.

Sustiprejusi ir įtakos igavusi IVT Vengrijos pirmininkavimo metu darbotvarkès formavimo funkciją visiškai perèmè į savo rankas. Kaip ir numatyta Lisabonos sutartyje, vengrai neturejo pirmininkavimo BSGP srityje programos, prioritetu, bet bande šioje srityje siūlyti ESVİ ir IVT pagalbą bei rekomendacijas. Vienas iš ES pareigūnų interviu pabrežè, kad pirmininkaujanti valstybè privalo įsiklausyti i Lisabonos sutarties reikalavimus ir prioritetų formavimo funkciją palikti ESVİ, todèl jis pataria, valstybès siūlomų rekomendacijų net nevadinti prioritetais, nes taip galima sukelti ESVI neigiamą reakciją. ${ }^{57}$ Vis dèlto Vengrijos patirtis rodo, kad ESVİ nèra linkusi atsižvelgti net ị gana neutralias rekomendacijas. Vengrijos atstoves teigimu, po Lisabonos sutarties ịsigaliojimo jau matesi, kad apie 99 proc. darbotvarkès kontroliuoja ESVİ, o vengrų pirmininkavimo metu tai išaugo iki 100 proc..$^{58}$ Airijos atstovas yra įsitikinęs, kad pirmininkaujanti valstybę įsigaliojus Lisabonos sutarčiai praktiškai prarado galimybę daryti įtaką darbotvarkei. Pirmininkaujanti valstybè gali prašyti įtraukti klausimus į darbotvarkę, bet sprendimus šiuo klausimu priima ESVİ ir IVT. ${ }^{59}$ Tiesa, IVT leidžia pirmininkaujančiai šaliai anksčiau negu kitoms susipažinti su tuo, kas bus darbotvarkëje, ji ir pirmininkauti besirengianti šalis dalyvauja visuose parengiamuosiuose susitikimuose. Tačiau šios šalys neturi netgi patariamojo balso. Vengrijos atstove tvirtina, kad, ko gero, vienintelę galimybę „tiesiogiai prisiliesti“ prie darbotvarkès formavimo vengrai turëjo sausio mènesị vykusio neformalaus gynybos politikos direktorių susitikimo metu Vengrijoje, kuomet dar nebuvo paskirti nei EDA, nei CMPD vadovai, ir pirmininkauti renginiui teko vengrams. Neformalaus ministrų susitikimo metu renginiui jau pirmininkavo ESVIt, ir nei IVT, nei ESVİ net nepapraše vengru

\footnotetext{
${ }^{55}$ Interviu su Belgijos atstovu, $2011 \mathrm{~m}$. gegužès $5 \mathrm{~d}$.

${ }^{56}$ Interviu su ES institucijų atstovu (I), $2011 \mathrm{~m}$. gegužès $24 \mathrm{~d}$.

${ }_{57}$ Ten pat..

${ }^{58}$ Interviu su Vengrijos atstove Briuselyje, $2011 \mathrm{~m}$. gegužès $4 \mathrm{~d}$.

${ }^{59}$ Interviu su Airijos atstovu Briuselyje, $2011 \mathrm{~m}$. gegužè $10 \mathrm{~d}$.
} 
pastabų dèl darbotvarkès. ${ }^{60}$ Taigi mažai tikètina, kad panašios galimybès galètų susiformuoti ateinančių pirmininkavimų metu, kai visu pagrindinių instituciju vadovai jau dirba.

Bandant prognozuoti, kuria linkme toliau judès galiu pasiskirstymas tarp ESVİ ir pirmininkaujančios valstybès, visų akys krypo ị Lenkiją. Viena vertus, tai didelius išteklius ir ịtaką turinti valstybè, antra, Lenkija yra viena iš Veimaro iniciatyvos šalių, ir, trečia, lenkai galëjo tikètis Maciejaus Popowskio (ESVI pavaduotojo saugumo klausimais) pagalbos, kuris iš principo bendroje saugumo ir gynybos politikoje gali būti tapatinamas su Vİ. Lietuvos atstovas tai patvirtino sakydamas, kad „iš pokalbių su lenkais galima daryti išvadą, kad jie savo pirmininkavimo planus sieja su Popowskiu, be jo nemato jokių galimybių." ${ }^{\text {"61 }}$ Kita vertus, lenkų stiprybe - žmogiškieji ištekliai. Lenkai galëjo sau leisti dalyvauti visose darbo grupèse. Dar neprasidejus pirmininkavimui kiekvienoje darbo grupeje dalyvavo bent po kelis Lenkijos atstovus ${ }^{62}$ Vis delto, nepaisant Lenkijos pasiryžimo imtis aktyvaus vaidmens siūlant ESVĮ naujas iniciatyvas bei siekiant paveikti darbotvarkę, verta pripažinti, kad Lenkijos pirmininkavimui baigiantis iš esmès nieko naujo BSGP klausimais ES darbotvarkëje neįvyko. Viena vertus, tai atsitiko dèl to, kad ES darbotvarkëje dominavo ekonominiai klausimai. Kita vertus, lenkų viltys, susijusios su Veimaro iniciatyva, žlugo del kitu šios iniciatyvos šaliu nesuinteresuotumo. ${ }^{63}$ Taigi galima teigti, kad nepaisant ambicijų ir dydžio pirmininkaujančios valstybès tiesioginès galimybès daryti poveikị oficialiai darbotvarkei yra minimalios.

Tačiau be tų beveik iki nulio sumažèjusių galimybių išlieka dar neformalūs ar netiesioginiai poveikio būdai. ES institucijų atstovas teigè, kad pirmininkaujančios valstybès galimybès formuoti BSGP darbotvarkę išlieka kuriant ịvairaus pobūdžio neoficialias pozicijas (angl non-papers). Jo teigimu, geros kokybès ir tinkama tematika parengtos bei padedančios BSGP judeti pirmyn pozicijos yra labai vertinamos ES institucijose ir turi daug galimybių patekti ị oficialią BSGP darbotvarkę. ${ }^{64}$ Airijos atstovas mano, kad šis įrankis buvo labai veiksmingas anksčiau (ypač neformalių susitikimų metu ar darbo grupése), bet dabar susiduria su dideliais jo panaudojimo sunkumais. Vienas pagrindinių iššukių - pailgèjęs klausimo patekimo ị oficialius lygmenis kelias. Viena iš to priežasčiu - tai, kad IVT vis dar trūksta žmogiškųjų išteklių. ${ }^{65}$ Siekiant ịtraukti vieną ar kitą klausimą i BSGP oficialią darbotvarkę šalies pirmininkavimo metu, ši turi pradèti veikti jau prieš porą metų. Pirmas

\footnotetext{
${ }^{60}$ Interviu su Vengrijos atstove Briuselyje, $2011 \mathrm{~m}$. gegužè 4 d..

${ }^{61}$ Interviu su Lietuvos atstovu Briuselyje (III), $2011 \mathrm{~m}$. gegužès $10 \mathrm{~d}$.

${ }^{62}$ Interviu su Lietuvos atstove Briuselyje (I), $2011 \mathrm{~m}$. balandžio $27 \mathrm{~d}$.

${ }^{63}$ Kaczynski P. M. Polish Council Presidency 2011: Ambitions and Limitations, SIEPS, 2011, p. 45.

${ }^{64}$ Interviu su ES institucijų atstovu (I), $2011 \mathrm{~m}$. gegužès $24 \mathrm{~d}$.

${ }^{65}$ Interviu su Airijos atstovu Briuselyje, $2011 \mathrm{~m}$. gegužès $10 \mathrm{~d}$.
} 
žingsnis - geru, visai ES ar didžiajai daliai narių aktualių „vizionieriškų" (angl. food for thought) poziciju formavimas. Antras - intensyvios derybos su valstybemis naremis ir ES institucijomis del paramos.$^{66}$ Vis delto netgi tai negarantuoja, kad klausimas pasieks darbotvarkę reikiamu momentu. Paskutiniaisiais metais IVT per daug kontroliuoja visus darbotvarkès lygmenis: gali priimti arba atmesti pasiūlymus tiesiog motyvuodama, kad yra kitų klausimų darbotvarkëje ir kad ji pilna. Kitas būdas netiesiogiai koreguoti darbotvarkę platinant neoficialias pozicijas pirmininkavimo metu - tai specifiniu klausimu sostinèje organizuojami seminarai.

Pažymètina, kad klausimus inicijuoti iš anksto rengiant neoficialias pozicijas gali tiek pirmininkaujanti, tiek nepirmininkaujanti valstybè. Todèl neformali darbotvarkès formavimo funkcija nèra pirmininkaujančiosios valstybès prerogatyva. Kad klausimas patektų i darbotvarkę, svarbiausia yra užsitikrinti kuo platesnę valstybių narių paramą, todè šia funkcija dažniausiai naudojasi galingosios valstybès, galinčios ką nors mainais pasiūlyti kitoms valstybèms narèms.

Darbotvarkès formavimas tiesioginiais poveikio būdais ịsigaliojus Lisabonos sutarčiai BSGP srityje praktiškai išnyksta. Tačiau negalima teigti, kad ši funkcija išnyksta iš viso. Kaip ir organizacinès funkcijos atveju - darbotvarkès formavimas tik įgauna neformalų pobūdį, t.y. išsakomos neoficialios pozicijos neformalių susitikimų metu arba gerokai prieš prasidedant pirmininkavimui bei vyksta neformalios derybos su kitomis valstybèmis naremis siekiant paramos siūlomai iniciatyvai.

\subsection{Tarpininkavimo funkcija}

Nors pagal Lisabonos sutarties filosofiją tarpininkavimo funkcijos tokios, kaip ji buvo suvokiama anksčiau, pirmininkaujanti valstybè nebetenka, vis deltto šioks toks tarpininkavimo vaidmuo išlieka. ES institucijų atstovas pabrežè, kad pirmininkavimas polisaboninëje aplinkoje visu pirma reiškia sklandžią komunikaciją tarp sričių, kuriose išliko valstybių narių pirmininkavimas, ir tų, kuriose jo nebeliko, t.y. PSK ir Tarybos sąveika su COREPER ir t.t. ${ }^{67}$ Kita svarbi tarpininkavimo funkcijos dalis - tarpininkavimas tarp ESVI, IVT ir valstybių narių. Lenkijos atstoves nuomone, „lengvinantis“ pirmininkavimas visų pirma ir reiškia tarpininkavimą. ,Jei siekiate inicijuoti kokias nors diskusijas, pirmas žingsnis derètis su valstybèmis naremis, ieškoti kompromisų. Taip pat labai svarbu nuolat palaikyti komunikaciją su IVT. “68 Taigi, tarpininkavimo funkcija išlieka, tačiau jos

\footnotetext{
${ }^{66}$ Interviu su Lenkijos atstove Briuselyje, $2011 \mathrm{~m}$. gegužès $18 \mathrm{~d}$.

${ }^{67}$ Interviu su ES institucijų atstovu (I), $2011 \mathrm{~m}$. gegužè $24 \mathrm{~d}$..

${ }^{68}$ Interviu su Lenkijos atstove Briuselyje, $2011 \mathrm{~m}$. gegužès $18 \mathrm{~d}$.
} 
pobūdis labai neapibrèžtas. Vieną dalị veiklos sričių, susijusių su tarpininkavimu, galima priskirti organizacinei funkcijai - tai sklandi tarpinstitucinè komunikacija bei komunikacija tarp skirtingu sričiu pirmininkavimo metu. Derybas su valstybėmis naremis galima įtraukti į darbotvarkès formavimo funkciją. Tačiau straipsnyje, siekiant aiškiau atskirti funkcijas ir pabrežti komunikacinès funkcijos svarbą, tarpininkavimo funkcija yra išskiriama atskirai.

Atlikta pirmininkavimo vaidmenų analizè rodo, kad nors iš principo pagrindinès pirmininkavimo funkcijos BSGP srityje įsigaliojus Lisabonos sutarčiai išliko, valstybès narès neteko didesnès dalies su šiomis funkcijomis susijusių veiklų. Taip pat ir pačios funkcijos smarkiai pakito. Pavyzdžiui, išauga neformalių veiksmų svarba, taip pat padideja neformalių renginių organizavimo reikšmé, prisideda koordinacijos su ESVİ ir IVT funkcija, didele dalis darbų persikelia iš Briuselio ị sostinę. Akivaizdu, kad funkciju persiskirstymas vis dar vyksta. Todèl kokios bus pirmininkavimo pagrindinès funkcijos $2013 \mathrm{~m}$. antrąji pusmetį, kol kas sudètinga prognozuoti. Prieš Lietuvą pirmininkausiančios mažesnès ir mažiau ambicijų BSGP turinčios Kipras, Danija ir Airija Lietuvai gali palikti nedaug veiksmų laisves BSGP. Vengrijos atstovè yra įsitikinusi, kad net jei lenkams pavyks valstybès pirmininkavimo BSGP srityje galias šiek tiek praplesti, po Kipro pirmininkavimo jos vèl susitrauks. ${ }^{69}$ Lietuvos atstovas teigia, kad Lietuvos pirmininkavimo atskaitos taškas turi būti nustatomas pasibaigus danų pirmininkavimui. ${ }^{70}$ Tikètina, kad Lietuvai gali likti vienintelis vaidmuo - organizuoti seminarus ir neformalius susitikimus sostinëje, ir tai jis bus daugiau administracinio pobūdžio. ${ }^{71}$

Susiaureję pirmininkaujančios valstybès vaidmenys BSGP bei abejotini rezultatai verčia užduoti klausimą, ar verta mažoms valstybèms investuoti savo ribotus išteklius ị pirmininkavimą šioje srityje, ar juos geriau nukreipti ị sritis, kuriose vis dar realiai vadovaujama. ES instituciju atstovas teige, kad pirmininkavimo BSGP srityje perdavimas ESVI̦ ir IVT atitinka Lisabonos sutarties filosofiją ir todèl neturetų pakenkti valstybès reputacijai. Jis pabrěze, kad tokiu atveju labai svarbu ši sprendimą kuo anksčiau pranešti ESVİ. Jo manymu, ESVİ tai priimtų kaip natūralų reiškinị. Bet kartu pripažįsta, kad minimaliai pirmininkauti vis vien teks, nes pirmininkavimo funkcija išlieka kai kuriose su BSGP susijusiose institucijose. ${ }^{72}$ Kitu apklausos dalyvių nuomone, toks pasirinkimas gali turèti neigiamos įtakos valstybès vertinimui. Vengrai pasirinko pasyvią dalyvavimo strategiją ir susilaukia

\footnotetext{
${ }^{69}$ Interviu su Vengrijos atstove Briuselyje, $2011 \mathrm{~m}$. gegužès $4 \mathrm{~d}$.

${ }^{70}$ Interviu su Lietuvos atstovu Briuselyje (III), $2011 \mathrm{~m}$. gegužès $10 \mathrm{~d}$.

${ }^{71}$ Interviu su Vengrijos atstove Briuselyje, $2011 \mathrm{~m}$. gegužès $4 \mathrm{~d}$.

72 Interviu su ES institucijų atstovu (I), $2011 \mathrm{~m}$. gegužè $24 \mathrm{~d}$.
} 
daug negatyvių reakcijų. Kita vertus, sąmoningas valstybès pasirinkimas visai nusišalinti nuo pirmininkavimo BSGP srityje gali sukelti įtarimų, kad pastaroji tuo rodo savo skeptišką požiūịi i i BSGP. Lietuvos atveju, tai gali būti siejama su ir taip aiškiai deklaruojamu NATO prioritetizavimu BSGP atžvilgiu.

\section{Efektyvaus pirmininkavimo kriterijai ir prielaidos}

Vieningos pirmininkavimo vertinimo formules nèra. Dauguma šią problematiką tiriančių akademikų sutinka, kad efektyviu galima laikyti tokị pirmininkavimą, kuris igalina sèkmingai užbaigti derybas tuo metu diskutuojamais klausimais, užtikrina kokybiškus derybų rezultatus, sukuria gerą derybinę atmosferą, pasiekia pirmininkavimo laikotarpiui užsibrežtus tikslus. ${ }^{73}$ Efektyvaus pirmininkavimo apibrěžimas priklauso ir nuo konkrečių klausimų, ir nuo to, kuriam vaidmeniui pirmininkaujanti valstybè teikia prioritetą apskritai. Pagal kontingentinę vadybos teoriją, kuri remiasi paklausos (kurią generuoja ES) ir pasiūlos (kurią teikia pirmininkaujanti valstybe்) modeliu ${ }^{74}$ sèkmingas pirmininkavimas yra toks, kuris atitinka tuo metu esančią pirmininkavimo vaidmens paklausą ir įsipareigojimai yra i̇vykdomi sèkmingai. Atsižvelgiant ị tai, kad pirmininkavimo funkcijos ịsigaliojus Lisabonos sutarčiai BSGP keitèsi, atitinkamai reikètų iš naujo įvertinti efektyvaus pirmininkavimo kriterijus. Lietuvos atstovas pabrežè, kad pirmininkaujant bet kurioje srityje labai svarbu yra nepamiršti, kad efektyvus pirmininkavimas - tai sklandus pirmininkavimas, o ne nacionalinių interesų atstovavimas bet kokia kaina. Jo manymu, pirmininkavimo sèkmę reikètų vertinti plačiau nei konkrečiu tikslų pasiekimą vienoje ar kitoje srityje: „svarbu kad pavyktų bendras pirmininkavimas, nes per tai apskritai tampame įtakingesni, gereja mūsų reputacija, stiprinami individualūs gebëjimai. Sklandus pirmininkavimas reiškia, kad prioritetai geri, įdomūs

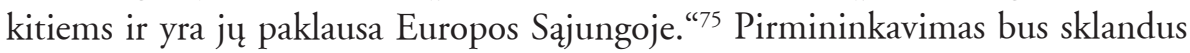
bei efektyvus taip pat tik tuo atveju, jei atlieps ES paklausą, t.y. bus daroma tai, ko ES, t.y. valstybès narès ir ES institucijos, nori iš pirmininkaujančios valstybès. Žinoma, situacija dar gali keistis, tačiau dabar, panašu, kad pirmininkaujančios valstybès pagrindinès funkcijos BSGP bus pusiau akademinių seminarų bei neformaliu susitikimu organizavimas. ES instituciju atstovas teigia, kad netgi jei pirmininkaujanti valstybe pasirinktų visiškai pasyvų vaidmenį, kai kurių funkcijų nepavyktų išvengti - pirmininkavimo institucijose, kuriose jis išlieka, ir komuni-

\footnotetext{
${ }^{73}$ Schout A., Vanhoonacker S., Evaluating Presidencies of the Council of the EU: Revisiting Nice, JCMS, Vol. 44, No. 5, p. 1056.

${ }^{74}$ Schout A., Vanhoonacker S. p. 1057.

${ }^{75}$ Interviu su Lietuvos atstovu (IV). $2011 \mathrm{~m}$. balandžio $28 \mathrm{~d}$.
} 
kacijos tarp šių institucijų ir tų, kur nelieka pirmininkavimo. Taip pat išliks tam tikrų funkciju ministrams. ${ }^{76}$ Taigi, nors „paklausa“ pirmininkavimui yra gerokai sumažejusi, ji išlieka.

\subsection{Organizacinè funkcija}

Beveik visi apklausos dalyviai pripažino, kad organizacine funkcija taps svarbiausia pirmininkaujančios valstybès funkcija BSGP srityje. Valstybe turi pasistengti surengti pakankamai neformalių renginių (neskaitant neformalių darbo grupių susitikimų) visai ES aktualiais klausimais. O kad pirmininkavimas būtų sèkmingas - valstybei narei patikèti organizaciniai darbai turi būti atlikti sklandžiai. Airijos atstovas, prisiminęs savo dalyvavimą Airijos pirmininkavimo komandoje $2004 \mathrm{~m}$. ir lygindamas ji su pirmininkavimu įsigaliojus Lisabonos sutarčiai, pripažista, kad skirtumai yra labai dideli. Visų pirma didžioji pirmininkaujančios valstybès darbo dalis keliasi iš Briuselio ị sostinę. Taigi, sklandu pirmininkavimą didele dalimi lemia geras darbas sostineje, t.y. įvairių neformalių susitikimų bei seminaru geras organizavimas. ${ }^{77}$ Belgijos atstovas taip pat atkreipe demesį, kad sklandus renginių organizavimas yra ypač svarbus sèkmingo pirmininkavimo elementas. Jo manymu, organizacinès nesèkmès dažnai tampa reikšmingesnés pirmininkavimo rezultatams nei turinys. Blogas laiko administravimas, kalendoriaus klaidos, prasta komunikacija - pagrindinès pirmininkaujančių valstybių klaidos. ${ }^{78}$ İvertinus tai, kad įsigaliojus Lisabonos sutarčiai BSGP svarbiausia funkcija tampa renginių organizavimas, jo reikšme kitų funkcijų kontekste labai išauga. Viena esminių sklandžios organizacijos prielaidu - glaudus bendradarbiavimas su ESVİ ir IVT. ${ }^{79}$ Vis dellto negalima neįvertinti ir to, kad dèl vis dar kylančių organizacinių ǐšǔkių IVT, glaudi koordinacija su IVT nèra labai paprastas procesas, todèl svarbu viską derinti iš anksto ir patiems viską tikrinti. Airijos atstovas teige, kad paskutinis prastos organizacijos pavyzdys buvo Vengrijos pirmininkavimo metu vykęs formalus gynybos ministrų susitikimas, kai IVT nesuderino darbotvarkès su Komisija ir ESVI tuo pačiu metu turejo dalyvauti abiejuose renginiuose. ${ }^{80}$ Tai gali turèti pasekmių pirmininkaujančiai valstybei, nes pirmininkaujančios šalies ministras turi formaliai atstovauti ESVIt, kai šis negali kur nors dalyvauti.

\footnotetext{
${ }^{76}$ Interviu su ES institucijų atstovu (I), $2011 \mathrm{~m}$. gegužès $24 \mathrm{~d}$.

${ }^{77}$ Interviu su Airijos atstovu Briuselyje, $2011 \mathrm{~m}$. gegužès $10 \mathrm{~d}$.

${ }^{78}$ Interviu su Belgijos atstovu, $2011 \mathrm{~m}$. gegužès $5 \mathrm{~d}$.

${ }^{79}$ Interviu su ES institucijų atstovu (I), $2011 \mathrm{~m}$. gegužès $24 \mathrm{~d}$.

${ }^{80}$ Interviu su Airijos atstovu Briuselyje, $2011 \mathrm{~m}$. gegužès $10 \mathrm{~d}$..
} 
Dar viena potenciali, mažai išnaudota galimybè - bendradarbiavimas organizaciniais klausimais, su trejeto valstybèmis dalijantis funkcijomis ir mažinant organizacines sąnaudas.

\subsection{Darbotvarkès formavimas}

Sèkmingai atliktos darbotvarkès formavimo funkcijos rezultatas - koks nors teisès aktas, rezoliucija, gairès ir panašiai. ${ }^{81}$ Tačiau ịsigaliojus Lisabonos sutarčiai tai tampa komplikuota, nes pirmininkaujanti valstybe neformuoja „oficialiosios“ darbotvarkès. ES instituciju atstovas teige, kad darbotvarkes formavimo klausimais pirmininkaujančiai šaliai belieka elgtis kaip paprastai valstybei. IVT gali konsultuotis su pirmininkaujančiąja, kviesti ją i parengiamuosius susitikimus, tačiau tai nereiškia, kad bus atsižvelgta ị jos pasiūlymus. ${ }^{82}$ Susiaurejusios galimybès formuoti darbotvarkę polisaboninëje erdvejje skatina pirmininkaujančiąsias ieškoti kitu būdų, kaip susieti ES vykstančius procesus su savo pirmininkavimo rezultatais. Formuojasi nauja tradicija, kai pirmininkaujanti šalis dar prieš pradedama pirmininkavimą bando ištirti IVT „poreikius“, t.y. kokie klausimai bus BSGP darbotvarkëje pirmininkavimo metu, kokių pozicijų reikètų laikytis. Reikalinga šiuos klausimus gerai išsistudijuoti, rengti pasiūlymus, ieškoti kitų valstybių narių paramos, pirmininkavimo metu išlaikyti „vientisą liniją“ organizuojant renginius, o pirmininkavimo pabaigoje pabrèžti, kad šie užsibrěžti rezultatai buvo pasiekti. Šios tradicijos pradininkai buvo belgai. Belgijos pirmininkavimas BSGP srityje buvo įvertintas kaip sèkmingas, jie glaudžiai bendradarbiavo su ESVİ bei IVT ir jiems pasiseke pasiekti, kad būtų atsižvelgiama ị jų siūlymus formuojant BSGP darbotvarkę. ES institucijų atstovas teige, kad nors belgai BSGP srityje neįtrauke nieko į pirmininkavimo programą, jiems sekèsi surengti nemaža sèkmingų renginių, kurių temos vèliau tapo darbotvarkès dalimi. Taip pat jie ESVİ bei IVT pasiūlè tokias temas, kurios buvo labai aktualios tiek valstybèms narems, tiek ESVİ. ${ }^{83}$ Tiesa, dali belgu sèkmés nulèmé tai, kad ju pirmininkavimo laikotarpiu IVT dar labai trūko žmogiškųjų išteklių ir ji labai priklause tiek šiuo požiūriu, tiek finansiškai nuo pirmininkaujančiosios valstybès, tačiau tokia belgu praktika išplito. Ja bande naudotis vengrai, lenkai, planuoja naudotis airiai ir lietuviai. Lietuvos atstovas teige, kad pirmininkavimo metu „mūsų tikslas - glaudžiai bendradarbiauti su IVT, analizuoti „rinką“, ko reikia, teikti siūlymus ten, kur jų reikia, ir bandyti sakyti,

\footnotetext{
${ }^{81}$ Interviu su Lietuvos atstovu (IV), $2011 \mathrm{~m}$. balandžio $28 \mathrm{~d}$..

${ }^{82}$ Interviu su ES institucijų atstovu (II), $2011 \mathrm{~m}$. gegužè $19 \mathrm{~d}$.

${ }^{83}$ Interviu su ES institucijų atstovu (I), $2011 \mathrm{~m}$. gegužès $24 \mathrm{~d}$.
} 
kad tai yra mūsų prioritetai. Taip pat labai svarbu suburti palaikančiu šalių grupę (nuolatos), nes kol nèra kitu narių palaikymo - nieko nę̨manoma padaryti."84

Belgijos atstovas pasakojo, kad diskusijas su ESVİ ir IVT dèl pirmininkavimo indèlio į BSGP darbotvarkę jie pradejo 2-3 ménesius prieš prasidedant pirmininkavimui, tačiau sostinëje ruoštis patare pradeti daug anksčiau, maždaug $2012 \mathrm{~m}$. vasarą ${ }^{85}$ Lenkijos atstove patare dar prieš prasidedant pirmininkavimui nuolat ir įdemiai sekti darbotvarkę, gerai parengti žmones, sukaupti žinių įvairiais BSGP klausimais. Taip pat kuo anksčiau pradèti diskusijas su valstybemis naremis dèl paramos prioritetiniais klausimais. ${ }^{86}$ Lietuvos atstovas tvirtino, kad polisaboninëje aplinkoje ypač svarbu suprasti šalių pozicijas kiekvienu klausimu bei gebèti jas projektuoti. ${ }^{87}$ Nepaisant pasikeitusio galios balanso, verta atsiminti, kad BSGP išlieka tarpvyriausybinè ir ESVI priklauso nuo valstybių narių, todèl šios gali jam formuoti užduotis. Jei klausimas gerai parengtas ir egzistuoja valstybių narių pritarimas, valstybès išlaiko galimybes veikti darbotvarkę. ${ }^{88} \mathrm{ES}$ institucijų atstovo nuomone, Veimaro iniciatyva yra puikus valstybiu nariu galių pavyzdys. ${ }^{89}$ Tačiau siekiant tokio poveikio būtina kuo platesnè valstybių narių parama, taip pat svarbu, kad iniciatyvą paremtų didžiosios valstybès. Kartais yra prasminga būti lankstiems ir „sulaukti tinkamo laiko“, kol vienas ar kitas prioritetas taps aktualus be jokiu pastangu. ${ }^{90} \mathrm{ES}$ institucijų atstovo manymu, dar vienas veiksnys, praplečiantis valstybiu įtakos ribas, - tai priejimas prie „vidines“ informacijos IVT, todèl labai rekomenduoja pirmininkaujančioms valstybems ị šią instituciją siųsti savo atstovus (liaison officer). ${ }^{91}$ Lietuvos atstoves manymu, pirmininkaujančios valstybès įtaką labai padidina aukštas ekspertizès lygmuo, gebëjimas kuo dažniau išsakyti savo poziciją kiekvienu klausimu. ${ }^{92}$ Tačiau šiais privalumais pasinaudoti gali tik didesnès valstybès, turinčios daugiau žmogiškųjų išteklių.

Kito Lietuvos atstovo nuomone, nevertetų pamiršti, kad valstybès išlaiko pirmininkavimą kai kuriais svarbiais su išorès santykiais susijusiais, t.y. prekybos ir vizų, klausimais. Valstybès narès taip pat vis dar pirmininkauja COREPER. Jis siūlo pasinaudoti šiomis dar išlikusiomis galimybèmis formuoti darbotvarkę. Pavyzdžiui, rytų kaimynystès tikslus igyvendinti šioje srityje siekiant palengvinti vizų režimą

\footnotetext{
${ }^{84}$ Interviu su Lietuvos atstovu Briuselyje (III), $2011 \mathrm{~m}$. gegužès $10 \mathrm{~d}$.

${ }^{85}$ Interviu su Belgijos atstovu, $2011 \mathrm{~m}$. gegužes $5 \mathrm{~d}$.

${ }^{86}$ Interviu su Lenkijos atstove Briuselyje, $2011 \mathrm{~m}$. gegužè $18 \mathrm{~d}$.

${ }^{87}$ Interviu su Lietuvos atstovu Briuselyje (II), $2011 \mathrm{~m}$. gegužès $4 \mathrm{~d}$.

${ }^{88}$ Interviu su ES institucijų atstovu (I), $2011 \mathrm{~m}$. gegužè $24 \mathrm{~d}$.

${ }^{89}$ Interviu su ES institucijų atstovu (II), $2011 \mathrm{~m}$. gegužè $19 \mathrm{~d}$.

${ }^{90}$ Interviu su ES institucijų atstovu (I), $2011 \mathrm{~m}$. gegužè $24 \mathrm{~d}$.

${ }^{91}$ Interviu su ES institucijų atstovu (II), 2011 m. gegužè 19 d.

${ }^{92}$ Interviu su Lietuvos atstove Briuselyje (I), $2011 \mathrm{~m}$. balandžio $27 \mathrm{~d}$.
} 
Gruzijai. ${ }^{93}$ Tai gali būti pritaikoma ir BSGP klausimams, pavyzdžiui, galima būtų ieškoti sąsajų tarp BSGP ir buvusio trečiojo ramsčio, BSGP ir prekybos.

\subsection{Tarpininkavimo funkcija}

İsigaliojus Lisabonos sutarčiai valstybè nare turi užtikrinti gerą koordinaciją tarp tų sričių, kuriose pirmininkavimas lieka valstybių kompetencijoje, ir tų, kur jis pereina į ES institucijų rankas. Šią funkciją galima išnaudoti perkeliant kai kuriuos BSGP darbotvarkès klausimus ị vis dar valstybių narių pirmininkaujamas sritis. Siekiant sèkmingai atlikti šią funkciją būtina gera pirmininkavimo komandos koordinacija, aiškus funkcijų pasidalijimas ir nuolatinis bendravimas su ESVĮ bei IVT. ${ }^{94}$ Svarbu laiku pradeti parengiamuosius darbus, glaudžiai bendradarbiaujant su IVT sudelioti kalendorių ir pasidalyti funkcijomis.

Tarpininkavimo funkcija išlieka ir derantis dèl valstybių narių paramos konkrečiais klausimais. Tokiu atveju tarpininkavimo sẻkmé priklauso nuo gero klausimo turinio išmanymo ${ }^{95}$, pasirengimo ir santykiu su kitomis valstybemis. Belgijos atstovas patare likus 8 menesiams iki pirmininkavimo parengti šalių interesų žemèlapi ir pagal ji identifikuoti potencialius partnerius ir oponentus, vèliau nuolat „matuoti valstybių temperatūrą" ivvairiais klausimais. ${ }^{96}$ Lietuvos atstovo manymu, Lietuva turetų išnaudoti dvišales derybas su kitomis šalimis, siekdama paramos savo pozicijoms ir siūlydama paramą mums mažiau svarbiais, bet toms šalims aktualiais klausimais. Jo manymu, BSGP srityje galima siūlyti prancūzams paramą gynybos pramonès srityje, tokiu būdu užsitikrinant ịtakingą remejją. ${ }^{97}$ Prieš prasidedant Lenkijos pirmininkavimui Lenkijos tarptautinių santykių centro atliktame tyrime buvo teigiama, kad Lenkijos išaugusių ambiciju realizavimas pirmininkavimo metu priklausys nuo jos gebëjimo aiškiai suformuluoti prioritetus bei juos formuoti kartu su partneriais. ${ }^{98}$ Nors didesnèms šalims lengviau užsitikrinti didžiųjų partnerių paramą, yra pastebèta, kad mažos valstybès

\footnotetext{
${ }^{93}$ Interviu su Lietuvos atstovu (IV), $2011 \mathrm{~m}$. balandžio $28 \mathrm{~d}$.

${ }^{94}$ Interviu su ES institucijų atstovu (I), $2011 \mathrm{~m}$. gegužès $24 \mathrm{~d}$.

95 Interview with Permanent Representation of Slovenia, Vanhoonacker S., Reslow N., The European External Action Service: Living Forwards by Understanding Backwards. European Foreign Affairs Review, No. 15, 2010, p. 21.

${ }^{96}$ Interviu su Belgijos atstovu, $2011 \mathrm{~m}$. gegužès $5 \mathrm{~d}$.

${ }^{97}$ Interviu su Lietuvos atstovu Briuselyje (II), 2011 m. gegužès 4 d.

${ }^{98}$ Vanhoonacker S., Pomorska K., Maurer H., The Council Presidencies and European Foreign Policy Challenges for Poland in 2011, Warsaw: Center for International Relations. http://csm.org.pl/fileadmin/files/Biblioteka CSM/Raporty_i_analizy/2010/1CSM_Raporty_i_Analizy\%20K\%20Pomorska.pdf [žiūrèta 20120209]
} 
yra mažiau įtariamos bandymais perkelti į darbotvarkę nacionalinius interesus ${ }^{99}$ ir todèl sulaukia kitų mažesnių valstybių paramos. ${ }^{100} \mathrm{Ne}$ ką mažiau svarbūs neformalūs santykiai su svarbiausiomis figūromis BSGP: Catherine Ashton, Maciejumi Popowskiu, darbo grupių ir komitetu pirmininkais. ${ }^{101}$ Lietuvai, pirmininkavimo naujokei, neturinčiai patirties, gerus santykius ir reputaciją dar teks užsitarnauti. Lietuvos atstovas teigè, kad Europos Sajungoje Lietuva kol kas yra šalis be veido ${ }^{102}$ ir todèl valstybių lūkesčiai mūsų atžvilgiu didele dalimi formuosis priklausomai nuo Lietuvos elgesio pirmininkavimo metu, tačiau neoficialių kontaktų paieška turètų prasidèti jau dabar.

\subsection{Kitos sẻkmingo pirmininkavimo prielaidos}

Apklausos dalyviai išskyrè dar keletą bendro pobūdžio prielaidų sèkmingam pirmininkavimui: tinkamas ambicijų lygmuo, geras funkcijų pasidalijimas ir gera koordinacija pirmininkavimo komandoje, politinè parama, stiprūs žmogiškieji ištekliai.

Siekiant sèkmingo pirmininkavimo būtina nusistatyti subalansuotą ambiciju lygmenị. Ambicijos turi būti „realistinès“, bet ne per mažos. Lietuvos atstovas teigé, kad „mažų valstybių įtaka pirmininkavimo metu išauga iki vidutinių valstybių (pavyzdžiui, Ispanijos) įtakos lygmens. Todèl ir elgesio formatus galima rinktis

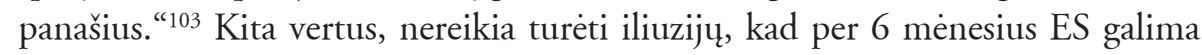
pasiekti rimtų pokyčiu. Tai ypač aktualu BSGP srityje. Todèl pirmininkavimo ambicijas BSGP reikia brěžti pagal tai, kas numatoma Lisabonos sutartyje, ir tai, ko pageidauja ESVI. ${ }^{104}$ Fatališkiausios pirmininkavimo klaidos - tai nesutarimai nacionaliniame lygmenyje dèl ambicijų lygmens bei per didelès ambicijos. ${ }^{105}$ Ambicijos taip pat turi atitikti turimus išteklius. Per didelès ambicijos verčia pirmininkaujančią valstybę daryti daug klaidų, taip pat kyla pavojus, kad dauguma tikslų liks neigyvendinti.

ES institucijų atstovas teige, kad siekiant gerų rezultatų reikia pradèti nuo sklandaus komandos darbo, o tam būtinas ne tik aiškus funkcijų pasidalijimas, bet ir bendradarbiavimas tarp institucijų. BSGP srityje ypač svarbus URM ir KAM

\footnotetext{
${ }^{99}$ Qaglia L. Moxon- Browne E., What Makes a Good EU Presidency? Italy and Ireland Compared. Journal of Common Market Studies, 44 (2), p. 360.

100 Ten pat.

${ }^{101}$ Interviu su ES institucijų atstovu (I), $2011 \mathrm{~m}$. gegužès $24 \mathrm{~d}$.

${ }^{102}$ Interviu su Lietuvos atstovu (IV), $2011 \mathrm{~m}$. balandžio $28 \mathrm{~d}$.

${ }^{103}$ Interviu su Lietuvos atstovu Briuselyje (III), $2011 \mathrm{~m}$. gegužès $10 \mathrm{~d}$.

${ }^{104}$ Interviu su ES institucijų atstovu (I), $2011 \mathrm{~m}$. gegužès $24 \mathrm{~d}$.

${ }^{105}$ Interviu su Belgijos atstovu, $2011 \mathrm{~m}$. gegužès $5 \mathrm{~d}$.
} 
bendradarbiavimas, kuris turi pasireikšti ne tik veiksmų vienybe, bet ir bendru požiūriu visais BSGP klausimais. Jis teige, kad pirmininkavimo istorijoje buvo keletas atvejų, kur būtent šių institucijų prasta koordinacija ar nesutarimai sužlugdè pirmininkavimą ${ }^{106} \mathrm{Ne}$ ką mažiau svarbi politine parama pirmininkavimui bei pirmininkavimo prioritetams. Pavyzdžiui, po rinkimų pasikeitusi valstybès pozicija vienu ar kitu klausimu gali rimtai pakenkti valstybès ịvaizdžiui bei pirmininkavimo sèkmei. Politiniam palaikymui užtikrinti vengrų pavyzdžiu būtų galima siekti partijų susitarimo, įpareigojančio garantuoti konsensusą pirmininkavimo metu. Lietuvos atstovas pabrèžè, kad rimtų problemų gali sukelti ir kai kurie aukščiausių vadovu pasisakymai, todèl reikia moketi suvaldyti tas rizikas. ${ }^{107}$

Viena svarbiausių gero pirmininkavimo prielaidu - tinkamai parinkti ir parengti žmonès. ES institucijų atstovas teigè, kad pirmininkavimo komandos žmonès turi labai gerai išmanyti polisaboninę struktūrą bei srities temas. Jis siūle formuojant pirmininkavimo komandą pasinaudoti Lietuvos pirmininkavimo ESBO patirtimi. ${ }^{108}$ Airijos atstovas teige, kad jie, rengdamiesi pirmininkavimui, daug dèmesio skiria ne tik žmonių parengimui, bet ir motyvacijai - suteikia jiems platesnius igaliojimus, sieja pirmininkavimą su karjeros galimybėmis. ${ }^{109}$ Tinkamas žmonių kiekis pirmininkavimo komandoje taip pat svarbus. Siekdama ji nusistatyti valstybè nare turi ịvertinti savo ambiciju lygị, taip pat pagalvoti, kiek žmonių reikes sostinëje, kiek Briuselyje, atsižvelgiant į tai, kad darbų apimčiu balansas kinta sostines naudai. Kiek žmonių reikia Briuselyje - apklausos dalyvių nuomonés išsiskyré, bet tai lèmé skirtinga pirmininkavimo patirtis. Belgijos atstovas tvirtino, kad žmogiškųjų išteklių reikia tiek pat, kiek ir pirmininkaujant prieš Lisabonos sutarties įsigaliojimą. ${ }^{110}$ Airijos atstovas teigè, kad dabartinèmis sąlygomis beveik nereikia plesti nuolat dirbančios komandos. Pirmininkavimo metu airiams reikès vieno papildomo reprezentacinio lygmens etato. ${ }^{111}$ Lietuvos atstove teigé, kad Lietuvos žmogiškujju išteklių problema yra dvilype - viena vertus, trūksta žmonių (Lietuva turi mažiau žmonių, kuruojančių BSGP klausimus Briuselyje, nei kitos valstybès), kita vertus, nèra išspręstas pastarųju pavaldumo klausimas. Lietuva neturi atskirų ES gynybos politikos patarejų, jie visi yra pavaldūs misijai prie NATO. ${ }^{12}$ Tai gali sudaryti sunkumu pirmininkavimo metu siekiant užtikrinti pirmininkavimo veiksmų vientisumą. ${ }^{113}$ Lietuvos atstove pabrežè, kad

\footnotetext{
${ }^{106}$ Interviu su ES institucijų atstovu (I), $2011 \mathrm{~m}$. gegužès $24 \mathrm{~d}$.

${ }^{107}$ Interviu su Lietuvos atstovu Briuselyje (II), 2011 m. gegužè 4 d..

${ }^{108}$ Interviu su ES institucijų atstovu (I), $2011 \mathrm{~m}$. gegužès $24 \mathrm{~d}$.

${ }^{109}$ Interviu su Airijos atstovu Briuselyje, $2011 \mathrm{~m}$. gegužè $10 \mathrm{~d}$.

${ }^{110}$ Interviu su Belgijos atstovu, $2011 \mathrm{~m}$. gegužès $5 \mathrm{~d}$.

${ }^{111}$ Interviu su Airijos atstovu Briuselyje, $2011 \mathrm{~m}$. gegužès $10 \mathrm{~d}$..

${ }^{112}$ Interviu su Lietuvos atstove Briuselyje (I), $2011 \mathrm{~m}$. balandžio $27 \mathrm{~d}$.

${ }^{113}$ Interviu su Lietuvos atstovu (IV), $2011 \mathrm{~m}$. balandžio $28 \mathrm{~d}$.
} 
pakankamas kiekis sostinëje pirmininkavimo srityje besidarbuojančių žmonių ir jų išmanymo lygis yra ne mažiau svarbus. ${ }^{114}$ Pirmininkaujanti šalis turi būti pasiruošusi ir nenumatytiems atvejams, pavyzdžiui, galimai krizei ir su ja susijusiai ES misijai. Iš pirmininkaujančios šalies ES tikisi, kad ji prisides prie ES misijos bent jau pirmininkavimo laikotarpiu. Vengrijos gynybos ministerija turëjo rezerve numatytų išteklių, jei ES būtų nusprendusi pradeti misiją Libijoje. ${ }^{15}$ Dar vienas svarbus aspektas - tinkamos sąlygos dirbti. ES institucijų atstovas pabreže plataus ir lankstaus mandato būtinybę pirmininkaujantiems Briuselyje, kad pastariesiems netektų kiekvienu smulkiu klausimu derintis su sostineje pirmininkaujančiais kolegomis. Koordinaciją su sostine labai padeda užtikrinti tinkami IT sprendimai. Išmanieji telefonai, videokonferenciju galimybès labai palengvina pirmininkavimo komandos darbą ir padidina efektyvumą. ${ }^{116}$

Svarbi pirmininkavimo prielaida - tai komunikacinis planas arba strategija. Pirmininkaujanti valstybè turi bendrą pirmininkavimo komunikacijos strategiją, bet svarbu nepamiršti, kad BSGP turi būti jos dalis. Gera komunikacinè strategija gali padidinti šalies matomumą pasaulyje, padeda suvaldyti įvairias potencialias rizikas, bet taip pat gali padidinti ES matomumą valstybès viduje. Pasinaudojant šia strategija, galima bandyti formuoti visuomenès paramą konkrečiais klausimais. Šia strategija pasinaudojant galima aiškinti Lietuvos vietą BSGP bei pasistengti užtikrinti didesnę paramą tiek BSGP, tiek Lietuvos karinių pajegų dalyvavimui BSGP. Kita vertus, ESVİ dažnai skundžiasi BSGP matomumo stoka, todèl gera komunikacinè strategija formuojant teigiamą BSGP įvaizdį Europoje ir valstybejje gali lemti didesnę ESVI paramą.

İvertinus apklausos dalyviu argumentus, galima išskirti keletą gero pirmininkavimo kriterijų. Pirma, pirmininkavimo funkcijos ir turinys turi būti labai tiksliai suderintas su ESVĮ ir atitikti ES „paklausą“. Antra, pirmininkavimas BSGP srityje turi būti suderintas su kitomis sritimis, kuriose valstybè pirmininkauja. Trečia, pirmininkavimo metu vykstantys renginiai turi būti organizuoti be priekaištų. Gero pirmininkavimo metu turi būti surengta bent keletas pusiau akademinių renginių BSGP pletotei svarbiomis temomis. Ketvirta, pirmininkavimo metu valstybė gali imtis tarpininko vaidmens, neformaliai bandydama užsitikrinti valstybių narių paramą vienu ar kitu darbotvarkès klausimu.

\footnotetext{
${ }^{114}$ Interviu su Lietuvos atstove Briuselyje (I), $2011 \mathrm{~m}$. balandžio $27 \mathrm{~d}$.

${ }^{115}$ Interviu su Vengrijos atstove Briuselyje, $2011 \mathrm{~m}$. gegužès 4 d.

${ }^{116}$ Interviu su ES institucijų atstovu (II), $2011 \mathrm{~m}$. gegužè 19 d.
} 


\section{Išvados}

Siekiant susumuoti ir apibendrinti pagrindinius naujos pirmininkavimo aplinkos bruožus svarbu pripažinti, kad ši institucine aplinka vis dar formuojasi, tebevyksta funkciju persiskirstymas. Penkios valstybes, pirmininkavusios po Lisabonos sutarties ịsigaliojimo, pirmininkavo skirtingomis sąlygomis, todèl labai sudètinga buvo rasti bendrus vardiklius, paaiškinančius tiek egzistuojančią institucinę aplinką, tiek formalius bei neformalius ryšius, tiek funkcijas ar efektyvaus pirmininkavimo kriterijus. Beveik visi interviu dalyviai pabrežè, kad iki Lietuvos pirmininkavimo tiek institucinè aplinka, tiek galimybès veikti ir efektyvumo kriterijai dar keisis, o tikslesnį Lietuvos pirmininkavimo galimybių paveikslą dèlioti bus galima tik po Danijos pirmininkavimo. Vis delto galima išskirti kelias pagrindines tendencijas, susijusias su pirmininkavimu BSGP srityje.

Pirma, galios balansas BSGP akivaizdžiai kinta ESVI ir IVT naudai. Ši tendencija stiprejja augant IVT.

Antra, nors tradiciniai pirmininkavimo vaidmenys BSGP išlieka ir įsigaliojus Lisabonos sutarčiai, tačiau pasikeite jų pobūdis, formalias renginių organizavimo, darbotvarkès formavimo ir tarpininkavimo funkcijas pakeite neformalios (neformalių renginių organizavimas, neformalių pozicijų formavimas, neformalus tarpininkavimas tarp valstybių narių ir ES institucijų). Tiesioginio pirmininkavimo BSGP institucijoms po Lisabonos sutarties praktiškai nebeliko.

Trečia, funkcijų pokytis koregavo sèkmingą pirmininkavimą nulemiančius veiksnius. Pastaruosius galima apibrěžti kaip: a) glaudus bendradarbiavimas su ESVI, IVT pagrindinemis BSGP srityje pirmininkaujančiomis institucijomis. Pirmininkavimo funkcijos ir turinys turi būti labai tiksliai suderintas su ESVİ ir atitikti ES „paklausą“; b) gera koordinacija tarp sričių, kuriose valstybe vis dar pirmininkauja, ir tų, kuriose ši funkcija perëjo ESVĮ; c) gera pirmininkavimo metu vykstančiu renginių organizacija; d) gerai atlikta tarpininkavimo funkcija derantis su valstybemis naremis dèl paramos. Sèkmingą šių veiksnių realizavimą didele dalimi lemia šios prielaidos: tinkamas ambicijų lygmuo, geras funkcijų pasidalijimas tiek su ESVĮ, tiek tarp pirmininkaujančiosios valstybes institucijų, gera koordinacija pirmininkavimo komandoje, politine parama šalyje ir stiprūs žmogiškieji ištekliai.

Jei dabartinès tendencijos stiprès, Lietuvai teksianti pirmininkavimo našta BSGP srityje nebus labai sunki, tačiau sèkmingai atlikti kad ir negausias užduotis pirmą kartą ES Tarybai pirmininkausiančiai Lietuvai bus rimtas iššūkis. Todèl svarbu šiam iššūkiui tinkamai pasiruošti. 